\title{
Testing DNA barcoding in Usnea (Parmeliaceae) in Colombia using the internal transcribed spacer (ITS)
}

\author{
Bibiana Moncada113, Harrie J. M. Sipman² \& Robert Lücking2,3*
}

\section{Article info}

Received: 13 Aug. 2020

Revision received: 11 Nov. 2020

Accepted: 11 Nov. 2020

Published: 29 Dec. 2020

\section{Associate Editor}

Camille Truong

\begin{abstract}
We tested the functionality of ITS-based DNA barcoding in lichen fungi using Colombian samples of the genus Usnea as an example. New ITS sequences were generated for 15 samples from five localities in two different ecoregions, representing varying morphologies and medullary chemistries. We employed five strategies to identify the samples: (1) BLASTn on the NCBI BLAST site with the original identifications of the best matching reference sequences; (2) as previous, but with revised identifications of the reference sequences based on a separately published revision of ITS sequences published for the genus; (3) local BLASTn in BioEdit using a separately published, revised and curated set of ITS reference sequences for the genus; (4) multiple alignment based phylogenetic analysis within the framework of all available ITS sequences for Usnea s.str.; and (5) integrative taxonomy, combining molecular phylogeny and comparative analysis of phenotype and chemical data. Using the latter approach as reference, we found that NCBI BLASTn with original identifications performed poorly, resulting in an identification success rate of only $7 \%$ (a single sample). NCBI BLASTn with revised identifications more than tripled identification success (23\%), but was still unsatisfactory. Local BLASTn in BioEdit using the revised, curated reference data further doubled identification success (47\%), but remained inadequate. Multiple alignment-based phylogenetic analysis achieved an identification success rate of $80 \%$ compared to the result from integrative taxonomy. Based on these results, we conclude that ITS-based DNA barcoding of the genus Usnea under the current circumstances performs poorly, but can be substantially improved using three strategies: (1) update identifications of reference sequences in primary repositories such as GenBank or alternatively use a curated reference data set; (2) perform local BLAST with a curated reference data set focusing on the target genus only, combined with multiple alignment-based phylogenetic analysis as a verification step; and (3) close substantial geographic and taxonomic gaps in the existing reference data. Our analyses suggest that if a near-complete reference data set with correct identifications existed for the genus, then standard BLAST approaches could achieve high levels of identification success close to $100 \%$. As part of our DNA barcoding exercise, which generated the first 15 ITS sequences for Colombian samples of the genus Usnea, we confirm the presence of $U$. aranea and $U$. wasmuthii in Colombia and we report for the first time $U$. tenuicorticata for the country.
\end{abstract}

Key words: Usnea columbiana, Usnea concinna, Usnea fruticans, Usnea macrura, Usnea nidulans, Usnea setulosa, Usnea sulphurascens

\section{Introduction}

DNA barcoding has become an important tool in mycology to provide species identifications or verify determinations based on phenotype characters (Begerow et al. 2010; Kelly et al. 2011; Schoch et al. 2012; Xu 2016;

\footnotetext{
${ }^{1}$ Licenciatura en Biología, Universidad Distrital Francisco José de Caldas, Cra. 4 No. 26D-54, Torre de Laboratorios, Herbario, Bogotá D.C., Colombia

2 Botanischer Garten und Botanisches Museum, Freie Universität Berlin, Königin-Luise-Straße 6-8, 14195 Berlin, Germany

${ }^{3}$ Research Associate, Integrative Research Center, The Field Museum, 1400 S Lake Shore Drive, Chicago, IL 60605, USA

* Corresponding author e-mail: r.luecking@bgbm.org
}

Truong et al. 2017; Hofstetter et al. 2019; Lücking et al. 2020a). Unfortunately, DNA barcoding of fungi (including lichens) has a number of challenges, including marker-specific limitations, the incompleteness of reference sequence databases, and the often incomplete or misleading sequence identifications (Vilgalys 2003; Nilsson et al. 2006, 2012; Bidartondo 2008; Tedersoo et al. 2011; Lücking et al. 2020a-c). The lichenized genus Usnea Dill. ex Adans. is no exception. In a detailed analysis of all available ITS barcoding data for this hyperdiverse genus (in the definition by Lücking et al. 2017a), Lücking et al. (2020c) demonstrated numerous shortcomings 
in sequence data pertaining to Usnea: first and foremost taxonomic and geographic gaps, but also substantial issues with sequence identifications and voucher information. In addition, species identification in Usnea is challenging, as many presumably widespread taxa represent complexes of partly unrelated lineages and much work remains to be done to fully resolve the taxonomy of this genus (Seymour et al. 2007; Wirtz et al. 2008, 2012; Lumbsch \& Wirtz 2011; Saag et al. 2011; Shen et al. 2012; Truong \& Clerc 2012, 2016; Truong et al. 2013a, b; Clerc 2016; Mark et al. 2016; Gerlach et al. 2017, 2019, 2020; Clerc \& Otte 2018; Grewe et al. 2018; Lagostina et al. 2018; Dorey et al. 2019; Temu et al. 2019; Lücking et al. 2020c).

Here we use Colombia as an example to illustrate the potential and the limitations of ITS-barcoding in the genus Usnea focusing on tropical species. South America has been identified as one of the better sampled regions in terms of molecular data for this genus (Lücking et al. 2020c), and a number of taxonomic and phylogenetic revisions have been published for this region in the past decade (Truong et al. 2011, 2013, b; Truong \& Clerc 2016; Gerlach et al. 2017, 2019, 2020; Bungartz et al. 2018). For Colombia, 63 species were listed in the Catalog of Lichens of Colombia (Sipman \& Aguirre-C. 2016), a number subsequently adjusted to 60, with six name changes (Lücking et al. 2020d). Furthermore, 20 species have been added since then, for a total of 80 (Pulido-Herrera \& Ramos-Montaño 2016; Truong \& Clerc 2016; Diaz-Escandón et al. 2016; Ramírez-Morán et al. 2016; Simijaca et al. 2018; Moncada et al., in prep.). This makes Colombia one of the countries with the highest presumed species richness reported for the genus Usnea; e.g., 92 species have been listed for all of North America north of Mexico (Esslinger 2019), an area 19 times larger than Colombia, 66 for Mexico (Herrera-Campos 2016), and just about three dozen species are known from Europe (Randlane et al. 2009).

Up to the present, no Colombian material of the genus Usnea has been used to generate ITS barcoding data (Lücking et al. 2020c). However, for 41 of the 80 species names reported for Colombia $(51 \%)$, barcoding data exist for material from other regions (Lücking et al. 2020c). While it is conceivable that neotropical species listed for the country, such as U. malmei Motyka, indeed occur there, the presence of presumably widespread taxa originally described from other regions, such as $U$. hirta (L.) Weber ex F.H.Wigg., is questionable, and barcoding data can help to elucidate these issues. We therefore used an opportunistic sample of 15 specimens representing 15 morphologically and chemically different 'taxa', collected in different Colombian ecoregions, to assess the success rate of ITS-based barcoding for species identifications. Based on the results, we also employed a simple prediction method to assess how complete the knowledge of Usnea in the Colombian lichen biota currently is, by comparing the proportion of already reported versus novel elements among the sequenced material.

We dedicate this paper to our esteemed colleague, Philippe Clerc, who recently retired from active duty as Head of the Herbarium at the Conservatoire et Jardin Botaniques de la Ville de Genève. With our study, we set out to demonstrate that DNA barcoding is not the fast, universal approach to species identifications that users would like to see. Instead, it requires a detailed follow-up to verify initial results, often arriving at different identifications. At some time in the future, when complete and accurate reference sequence databases are available, DNA barcoding will become a routine approach. Until then, it is the hard work of expert taxonomists, such as Philippe, his colleagues and students, that provides the basis for molecular identifications by sorting out species and their nomenclature, arriving at a solid alpha taxonomy through years of studying collections, reference material and historical literature, and reconciling this information with molecular phylogenies. We hope that Philippe will have many more years to continue this indispensable task.

\section{Material and methods}

New ITS sequences were generated for 15 specimens of the genus Usnea collected in two ecologically disparate departments (Cundinamarca, Putumayo) and five localities in Colombia (Fig. 1).

Molecular work was performed in the Pritzker Laboratory for Molecular Systematics and Evolution of the Field Museum and in the molecular laboratories of the Botanischer Garten und Botanisches Museum, Freie Universität Berlin. DNA was extracted from each sample using the SIGMA REDExtract-N-Amp ${ }^{\text {TM }}$ Plant Tissue PCR Kit (St. Louis, Missouri, SA) for DNA isolation following the manufacturer's instructions, but with lower proportions for lower amounts of DNA. Dilutions of either 10:1 or 100:1 were used for PCR amplifications, with the primer pairs ITS1F and ITS4 (Gardes \& Bruns 1993; White et al. 1990). The $25 \mu \mathrm{L}$ PCR reactions contained $2.5 \mu \mathrm{L}$ buffer, $2.5 \mu \mathrm{L}$ dNTP mix, $1 \mu \mathrm{L}$ of each primer $(10 \mu \mathrm{M}), 5 \mu \mathrm{L}$ BSA, $2 \mu \mathrm{L}$ Taq (either Taq provided with the SIGMA REDExtract-N-Amp ${ }^{\mathrm{TM}}$ Plant Tissue PCR Kit or peqGOLD Taq-Polymerase, VWR), $2 \mu \mathrm{L}$ genomic DNA extract and $9 \mu \mathrm{L}$ distilled water. The thermal cycling parameters were set as follows: initial denaturation for $3 \mathrm{~min}$ at $95^{\circ} \mathrm{C}$, followed by 30 cycles of $1 \mathrm{~min}$ at $95^{\circ} \mathrm{C}$, $1 \mathrm{~min}$ at $52^{\circ} \mathrm{C}, 1 \mathrm{~min}$ at $73^{\circ} \mathrm{C}$, and final elongation for $7 \mathrm{~min}$ at $73^{\circ} \mathrm{C}$. Amplification products were separated on $1 \%$ agarose gels stained with ethidium bromide. Purification was done either by cutting the target bands and employing the QIAGEN QIAquick PCR Purification Kit (Hilden, Germany) or the MACHEREY-NAGEL Nucleo Spin DNA purification kit (Düren, Germany), or by applying the THERMO-FISHER ExoSAP-IT ${ }^{\mathrm{TM}}$ PCR Product Cleanup (Waltham, Massachussetts) directly to the PCR product. At the Field Museum, fragments were sequenced using the ABI PRISM Big Dye Terminator reaction kit (Applied Biosystems). Sequencing and PCR amplifications were performed using the same sets of primers. Cycle sequencing was executed with the following setting: 25 cycles of $95^{\circ} \mathrm{C}$ for $30 \mathrm{sec}, 48^{\circ} \mathrm{C}$ for $15 \mathrm{sec}, 60^{\circ} \mathrm{C}$ for $4 \mathrm{~min}$. Sequenced products were precipitated with $10 \mu \mathrm{L}$ of sterile $\mathrm{dH}_{2} \mathrm{O}, 2 \mu \mathrm{L}$ of $3 \mathrm{M}$ Napa, and $50 \mu \mathrm{L}$ of $95 \% \mathrm{EtOH}$ and subsequently loaded on an ABI 3100 (Applied Biosystems) automatic sequencer. 


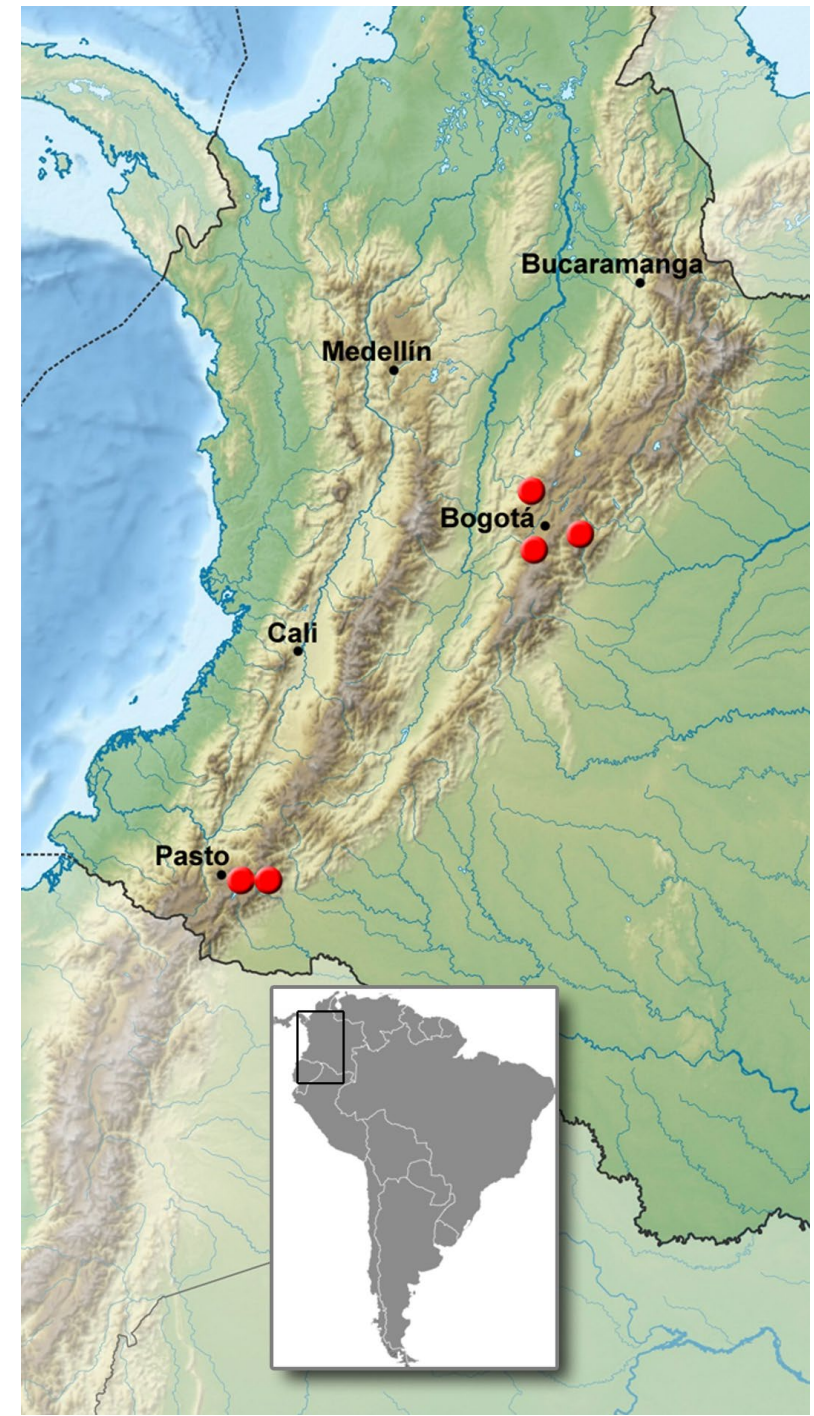

Figure 1. Map of the five sampling localities in Colombia. Base map taken from Wikimedia Commons [https://upload.wikimedia.org/wikipedia/commons/2/2b/Colombia_relief_location_map.jpg].

At the Botanischer Garten und Botanisches Museum, Freie Universität Berlin, cycle sequencing was carried out by MACROGEN Europe (Amsterdam, The Netherlands) using the same primers as in the PCR reactions. Sequence reads were assembled with DNASTAR SeqMan 4.03 and GENEIOUS 8.1.0, manually inspected and adjusted and, after quality control within the context of multiple alignments, submitted to GenBank (Table 1).

DNA barcoding was done in three steps. In the first step, we blasted the query sequences in the BLASTn suite [https://blast.ncbi.nlm.nih.gov/Blast.cgi?PROGRAM=blastn\&PAGE_TYPE=BlastSearch\&LINK_LOC=blasthome] using BLASTn with default settings. For each query sequence, we recorded the three best hits based on maximum score, plus up to three additional hits with a percentage identity of $98.5 \%$ or higher when present among the result, thereby using the default threshold for species hypotheses in the curated fungal ITS database UNITE (Abarenkov et al. 2010; Kõljalg et al. 2013, 2019; Nilsson et al. 2019; Lücking et al. 2020a). The result was analyzed both based on the original identifications and the corrected identifications as assessed by Lücking et al. (2020c). In a second step, we blasted the same query sequences locally in BioEdit 7.2.5 (Hall 1999, 2011) using the 'Usnea ITS Barcoding Release 1.0' provided by Lücking et al. (2020c) with the following settings: program $=$ BLASTn; E value $=1.0^{-100}$; matrix $=$ BLOSUM62; max number of hits to report $=10$; threshold for extending hit $=0$.

Finally, we aligned the query sequences with the global ITS alignment for the genus Usnea assembled by Lücking et al. (2020c), originally consisting of 1,756 ingroup terminals. Since all 15 query sequences belonged in Usnea s.str., the final analysis was done with a subset corresponding to Usnea s.str. with selected sequences of Dolichousnea (Y. Ohmura) Articus and Eumitria Stirt. as outgroup and a total of 918 ingroup reference sequences (File S1). A maximum likelihood tree was reconstructed with RAxML 8 (Stamatakis 2014) using the RAxML-HPC Blackbox 8.2.12 on the CIPRES Science Gateway (Miller et al. 2010). We employed the GTR-Gamma model with an automatically determined number of 403 bootstrap pseudoreplicates determined by a saturation criterion.

To assess the morphology, anatomy, and medullary chemistry of the sequenced specimens, we examined them using established protocols (Clerc 1987, 2007; Gerlach et al. 2017, 2019; Halonen et al. 1998, 1999; Herrera-Campos 2016; Mark et al. 2016; Ohmura 2001, 2012; Randlane et al. 2009; Truong \& Clerc 2016; Truong et al. 2013b). For morphological and anatomical observations, we used a LEICA Zoom 2000 dissecting microscope. Thin-layer chromatography (TLC) was performed according to Orange et al. (2010) using solvent C. We compared the identifications of the 15 sequenced samples with the 80 names currently listed for Colombia to arrive at a simple prediction of the total number of Usnea species possibly occurring in Colombia, assuming that the 15 sequenced species represent a stochastic sample relative to the 80 reported species. For instance, if all 15 sequenced samples corresponded to already reported names, then the number of 80 species would be assumed to be representative. If only five out of the 15 species corresponded to a listed species, then one would assume that the actual number could be three times higher than 80 , i.e., 240. The underlying formula to be applied is $\mathrm{S}=80 \times$ $15 / N$, where $\mathrm{S}=$ estimated total richness and $\mathrm{N}=$ number of species shared between sequenced and listed taxa.

\section{Results and discussion}

BLAST results. NCBI BLASTn resulted in a total of 14 different potential identifications for the 15 query sequences, taking into account the three best hits plus up to three addition hits with a percentage identity of $98.5 \%$ or higher (Table 2). These were (in alphabetical order) Usnea ceratina Ach., U. cornuta Körb., U. glabrescens (Nyl. ex Vain.) Vain., U. halei P. Clerc, U. aff. ignaria Motyka, U. intermedia (A. Massal.) Jatta, U. lapponica Vain., U. rubrotincta Stirt., U. subantarctica F.J. Walker, U. subfusca Stirt., U. subscabrosa Nyl. ex Motyka, U. substerilis Motyka, U. wasmuthii Räsänen, and Usnea sp. Only three query sequences had potential 
Table 1. Voucher information for the 15 Colombian samples of the genus Usnea used for this barcoding study. The taxa are given as Usnea sp. in the table, but were submitted under the names applied in the taxonomic section below.

\begin{tabular}{l|l|l|l}
\hline Taxon & Isolate & \multicolumn{1}{|c|}{ Voucher } & ITS Accession \\
\hline Usnea sp. & DB22576 & Colombia, Moncada \& Lücking 41018b (B 60 0200038) & MW241067 \\
Usnea sp. & DB22608 & Colombia, Moncada \& Lücking 41047a (B 60 0200039) & MW241068 \\
Usnea sp. & DB22609 & Colombia, Moncada \& Lücking 41048a (B 60 0200041) & MW241069 \\
Usnea sp. & DB22615 & Colombia, Moncada \& Lücking 41047b (B 60 0200040) & MW241070 \\
Usnea sp. & DB22625 & Colombia, Moncada \& Lücking 41058c (B 60 0200042) & MW241071 \\
Usnea sp. & DB22638 & Colombia, Moncada \& Lücking 41067 (B 60 0200043) & MW241072 \\
Usnea sp. & DB22671 & Colombia, Moncada \& Lücking 41099 (B 60 0200044) & MW241073 \\
Usnea sp. & DB22672 & Colombia, Moncada \& Lücking 41100 (B 60 0200045) & MW241074 \\
Usnea sp. & MON5335 & Colombia, Rivera \& Salinas 72 (B 60 0200046) & MW241075 \\
Usnea sp. & MON5349 & Colombia, Rivera \& Salinas 87 (B 60 0200047) & MW241076 \\
Usnea sp. & MON5795 & Colombia, Moncada \& Lücking 11069 (B 60 0200048) & MW241077 \\
Usnea sp. & MON5866 & Colombia, Moncada et al. 10870 (B 60 0200049) & MW241078 \\
Usnea sp. & MON6140 & Colombia, Moncada \& Patiño 11399 (B 60 0200050) & MW241079 \\
Usnea sp. & MON6229 & Colombia, Moncada \& Patiño 11272a (B 60 0200051) & MW241080 \\
Usnea sp. & MON6230 & Colombia, Moncada \& Patiño 11272b (B 60 0200053) & MW241081 \\
\hline
\end{tabular}

hits with a percentage identity of $98.5 \%$ or higher, seven had at best close matches between $97.0 \%$ and $98.5 \%$, and five had only distant matches below $97.0 \%$ (Fig. 2). Individual query sequences had up to five different names as best hits (Table 2, Fig. 2). Taking into account only the hits with the highest percentage identity for each query sequence, the identifications included only six full names, i.e., Usnea ceratina (1), U. halei (1), U. intermedia (3), U. subfusca (1), U. substerilis (2), and U. wasmuthii (1), and several unresolved identifications as Usnea sp. (7).

Keeping the NCBI BLASTn results, but replacing the corresponding sequence identifications for each reference

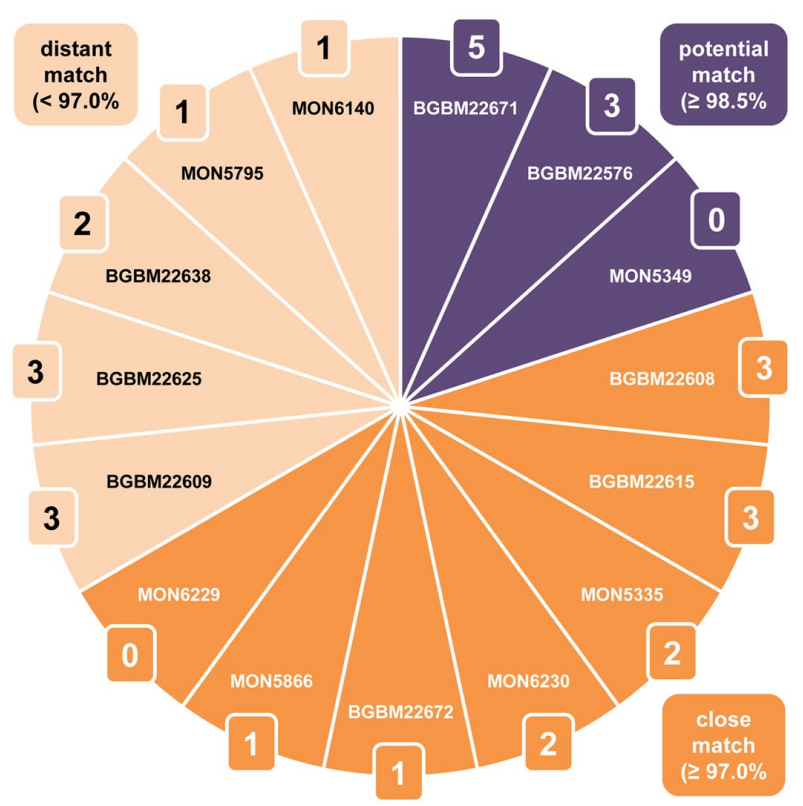

Figure 2. NCBI BLASTn 'Barcoding wheel' for the 15 query sequences of the genus Usnea from Colombia. Each pie represents one query sequence and the colors correspond to levels of percentage identity: purple $=98.5 \%$ or higher, orange $=$ between $97 \%$ and $98.5 \%$, beige $=$ below $97 \%$. The numbers indicate the amount of different names appearing among the best BLAST hits (see Table 2). Ideally, the barcoding wheel should be purple throughout and have one precise name among the best BLAST hits, so this graphic abstraction allows a quick assessment how DNA barcoding is performing in a set of query sequences. accession with the adjusted identifications provided by Lücking et al. (2020c) resulted in a total of 22 different potential identifications for the 15 query sequences: $U$. aranea Truong \& P. Clerc, $U$. aff. ceratina, $U$. aff. confusa Asahina, U. aff. cornuta, U. glabrata (Ach.) Vain., U. glabrescens, U. halei, U. aff. halei, U. aff. ignaria, $U$. intermedia, U. lapponica, U. pacificana Halonen, $U$. perhispidella J. Steiner, U. aff. rubicunda Stirt., U. subantarctica, U. subflammea P. Clerc, U. subfusca, U. subscabrosa, U. aff. viktoriana P. Clerc \& Otte, U. wasmuthii, Usnea sp. 1 (JAM), and Usnea sp. 20 (Table 2). Of these, only nine out of these 22 names agreed with the original identifications for these reference sequences, namely $U$. glabrescens, $U$. halei, $U$. aff. igniaria, $U$. intermedia, U. lapponica, U. subantarctica, U. subfusca, U. subscabrosa, and $U$. wasmuthii, whereas 13 names corresponded to species not obvious from the original identifications. This resulted in an overlap between original and adjusted names of just $41 \%$. Taking into account only the hits with the highest percentage identity for each query sequence, the corrected identifications included eight full names, U. aranea (1), U. halei (1), U. intermedia (2), U. lapponica (1), U. pacificana (1), U. perhispidella (2), U. subfusca (2), and U. wasmuthii (1), three names with tentative identifications, namely $U$. aff. ceratina (2), $U$. aff. confusa (1), and $U$. aff. viktoriana (1), and two unresolved names, Usnea sp. 1 (JAM) (2) and Usnea sp. 20 (1). Among the fully named potential identifications, only four $(50 \%)$ overlapped with the original BLASTn identifications.

Between the original and the corrected BLASTn identifications, only six of the 15 query sequences $(40 \%)$ obtained the same potential identification, whereas for nine $(60 \%)$ it was different (Table 2; Fig. 3). Among original identifications, roughly $20 \%$ represented unresolved names (Usnea sp.), whereas the corrected names were completely resolved, although in many cases representing provisional names only (Table 2; Fig. 3). Most of the differences applied to names either appearing as close or distant hits only or to names with qualifiers. Only two full names appearing as potential matches were 
Table 2. NCBI BLASTn suite results for the 15 query ITS sequences. For each query sequence, the three best hits (based on maximum score) are given, plus up to three additional hits with high percentage identity. Accession = GenBank accession number for the corresponding hits; Original ID = identification on submitted reference sequence; Corrected ID = correct identification according to Lücking et al. (2020c); MS = Maximum score; QC = Query cover; PI = Percentage identity; Class = classification; potential = potential match $(98.5 \%$ or higher $)$, close $=$ close match (between $97.0 \%$ and $98.5 \%$ ), distant = distant match (below 97.\%); Inferred ID = most likely identification based on the highest percentage identity and precision of the corrected ID. The asterisk marks the only instance of a BLAST hit also related in the phylogenetic analysis.

\begin{tabular}{|c|c|c|c|c|c|c|c|c|}
\hline Query & Accession & Original ID & Corrected ID & MS & $\mathrm{QC}$ & PI & Class & Inferred ID \\
\hline \multirow[t]{6}{*}{ DB22576 } & MG262534 & subfusca & subfusca & 1028 & $100 \%$ & $98,5 \%$ & potential & wasmuthii \\
\hline & KX132920 & intermedia & intermedia & 1008 & $97 \%$ & $98,8 \%$ & potential & \\
\hline & KX132919 & intermedia & intermedia & 1008 & $97 \%$ & $98,8 \%$ & potential & \\
\hline & ${ }^{*} \mathrm{JN} 086334$ & wasmuthii & wasmuthii & 989 & $92 \%$ & $\underline{100 \%}$ & potential & \\
\hline & *JN086331 & wasmuthii & wasmuthii & 985 & $92 \%$ & $\underline{99,8 \%}$ & potential & \\
\hline & MK812501 & wasmuthii & wasmuthii & 974 & $91 \%$ & $\underline{99,8 \%}$ & potential & \\
\hline \multirow[t]{3}{*}{ DB22608 } & MG262534 & subfusca & subfusca & 1014 & $100 \%$ & $98,0 \%$ & close & aff. viktoriana \\
\hline & DQ219307 & aff. ignaria & aff. ignaria & 994 & $100 \%$ & $97,3 \%$ & close & \\
\hline & KX132928 & substerilis & aff. viktoriana & 988 & $96 \%$ & $\underline{98,1 \%}$ & close & \\
\hline \multirow[t]{3}{*}{ DB22609 } & MG262534 & subfusca & subfusca & 941 & $100 \%$ & $95,5 \%$ & distant & aff. intermedia \\
\hline & KX132919 & intermedia & $\underline{\text { intermedia }}$ & 941 & $97 \%$ & $\underline{96,2 \%}$ & distant & \\
\hline & DQ219307 & aff. ignaria & aff. ignaria & 940 & $100 \%$ & $95,5 \%$ & distant & \\
\hline \multirow[t]{3}{*}{ DB22615 } & MG262534 & subfusca & $\underline{\text { subfusca }}$ & 1011 & $100 \%$ & $\underline{98,0 \%}$ & close & cf. subfusca \\
\hline & KX132919 & intermedia & intermedia & 969 & $96 \%$ & $97,6 \%$ & close & \\
\hline & KX132928 & substerilis & aff. viktoriana & 966 & $96 \%$ & $97,4 \%$ & close & \\
\hline \multirow[t]{3}{*}{ DB22625 } & MG262534 & subfusca & subfusca & 950 & $99 \%$ & $95,8 \%$ & distant & aff. intermedia \\
\hline & KX132919 & intermedia & intermedia & 950 & $97 \%$ & $\underline{96,6 \%}$ & distant & \\
\hline & DQ219307 & aff. ignaria & aff. ignaria & 949 & $99 \%$ & $95,8 \%$ & distant & \\
\hline \multirow[t]{4}{*}{ DB22638 } & LC479125 & rubrotincta & aff. rubicunda & 977 & $99 \%$ & $96,8 \%$ & distant & aff. confusa \\
\hline & DQ232664 & rubrotincta & aff. rubicunda & 977 & $99 \%$ & $96,8 \%$ & distant & \\
\hline & LC479123 & cornuta & aff. cornuta & 976 & $98 \%$ & $97,3 \%$ & distant & \\
\hline & MT553315 & Usnea sp. & aff. confusa & 967 & $95 \%$ & $\underline{97,9 \%}$ & distant & \\
\hline \multirow[t]{6}{*}{ DB22671 } & MG262534 & subfusca & subfusca & 1007 & $100 \%$ & $98,0 \%$ & potential & pacificana \\
\hline & KX132919 & intermedia & intermedia & 1003 & $97 \%$ & $98,6 \%$ & potential & \\
\hline & KX132930 & lapponica & lapponica & 993 & $97 \%$ & $98,3 \%$ & potential & \\
\hline & ${ }^{*} \mathrm{JN086328}$ & substerilis & pacificana & 983 & $92 \%$ & $\underline{99,8 \%}$ & potential & \\
\hline & JN086329 & substerilis & glabrescens & 965 & $92 \%$ & $99,1 \%$ & potential & \\
\hline & AB051639 & glabrescens & glabrescens & 949 & $90 \%$ & $99,3 \%$ & potential & \\
\hline \multirow[t]{3}{*}{ DB22672 } & HQ671307 & Usnea sp. & perhispidella & 994 & $99 \%$ & $\underline{97,2 \%}$ & close & cf. perhispidella \\
\hline & LC479125 & rubrotincta & aff. rubicunda & 963 & $100 \%$ & $95,8 \%$ & distant & \\
\hline & DQ232664 & rubrotincta & aff. rubicunda & 963 & $100 \%$ & $95,8 \%$ & distant & \\
\hline \multirow[t]{4}{*}{ MON5335 } & MG262534 & subfusca & $\underline{\text { subfusca }}$ & 1018 & $100 \%$ & $\underline{98,0 \%}$ & close & cf. subfusca \\
\hline & KX132920 & intermedia & intermedia & 985 & $96 \%$ & $97,9 \%$ & close & \\
\hline & KX132919 & intermedia & intermedia & 981 & $96 \%$ & $97,8 \%$ & close & \\
\hline & JN086313 & intermedia & lapponica & 941 & $92 \%$ & $98,0 \%$ & close & \\
\hline \multirow[t]{3}{*}{ MON5349 } & MT553280 & Usnea sp. & aranea & 1032 & $98 \%$ & $\underline{98,8 \%}$ & potential & aranea \\
\hline & MT553285 & Usnea sp. & $\underline{\text { aranea }}$ & 985 & $93 \%$ & $\underline{99,3 \%}$ & potential & \\
\hline & MN006801 & Usnea sp. & glabrata & 959 & $98 \%$ & $96,4 \%$ & distant & \\
\hline \multirow[t]{3}{*}{ MON5795 } & MK010860 & Usnea sp. & Usnea sp. 20 & 962 & $100 \%$ & $96,1 \%$ & distant & aff. ceratina \\
\hline & KY033353 & ceratina & $\underline{\text { aff. ceratina }}$ & 961 & $100 \%$ & $\underline{96,1 \%}$ & distant & \\
\hline & MT553305 & Usnea sp. & aff. halei & 956 & $100 \%$ & $95,8 \%$ & distant & \\
\hline \multirow[t]{4}{*}{ MON5866 } & KY033353 & ceratina & aff. ceratina & 997 & $99 \%$ & $97,2 \%$ & close & cf. perhispidella \\
\hline & MG242037 & subscabrosa & subscabrosa & 987 & $99 \%$ & $96,8 \%$ & distant & \\
\hline & MT553306 & Usnea sp. & subflammea & 982 & $99 \%$ & $96,7 \%$ & distant & \\
\hline & HQ671307 & Usnea sp. & perhispidella & 969 & $95 \%$ & $\underline{97,9 \%}$ & close & \\
\hline \multirow[t]{3}{*}{ MON6140 } & MT553302 & Usnea sp. & Usnea sp. 1 (JAM) & 903 & $99 \%$ & $\underline{94,1 \%}$ & distant & Usnea sp. \\
\hline & EF179806 & subantarctica & subantarctica & 875 & $100 \%$ & $93,0 \%$ & distant & \\
\hline & EF179805 & subantarctica & subantarctica & 875 & $100 \%$ & $93,0 \%$ & distant & \\
\hline \multirow[t]{3}{*}{ MON6229 } & MT553302 & Usnea sp. & $\underline{\text { Usnea sp. } 1 \text { (JAM) }}$ & 984 & $99 \%$ & $\underline{97,0 \%}$ & close & Usnea sp. \\
\hline & MG262534 & subfusca & subfusca & 940 & $100 \%$ & $95,3 \%$ & distant & \\
\hline & KX132919 & intermedia & intermedia & 935 & $97 \%$ & $95,9 \%$ & distant & \\
\hline \multirow[t]{3}{*}{ MON6230 } & KY033353 & ceratina & $\underline{\text { aff. ceratina }}$ & 943 & $100 \%$ & $\underline{97,3 \%}$ & close & aff. ceratina \\
\hline & MG252375 & halei & halei & 939 & $100 \%$ & $\overline{97,3 \%}$ & close & \\
\hline & MT553305 & Usnea sp. & aff. halei & 939 & $99 \%$ & $97,1 \%$ & close & \\
\hline
\end{tabular}


different between both approaches: U. substerilis was found as potential match among the original, but not the corrected names, whereas $U$. aranea was found as potential match among the corrected but not the original names (Table 2; Fig. 3).

Local BLASTn in BioEdit using the 'Usnea ITS Barcoding Release 1.0' provided by Lücking et al. (2020c) was only partly congruent with NCBI BLASTn, even when the latter was replaced with the revised reference sequence identifications, resulting in identical identifications for only six out of 15 query sequences (Table 3). For the remaining nine query sequences, identifications based on the best matching hits changed as follows, including an additional four names (in boldface) not previously recovered through the two previous searches based on NCBI BLASTn with original and revised identifications:
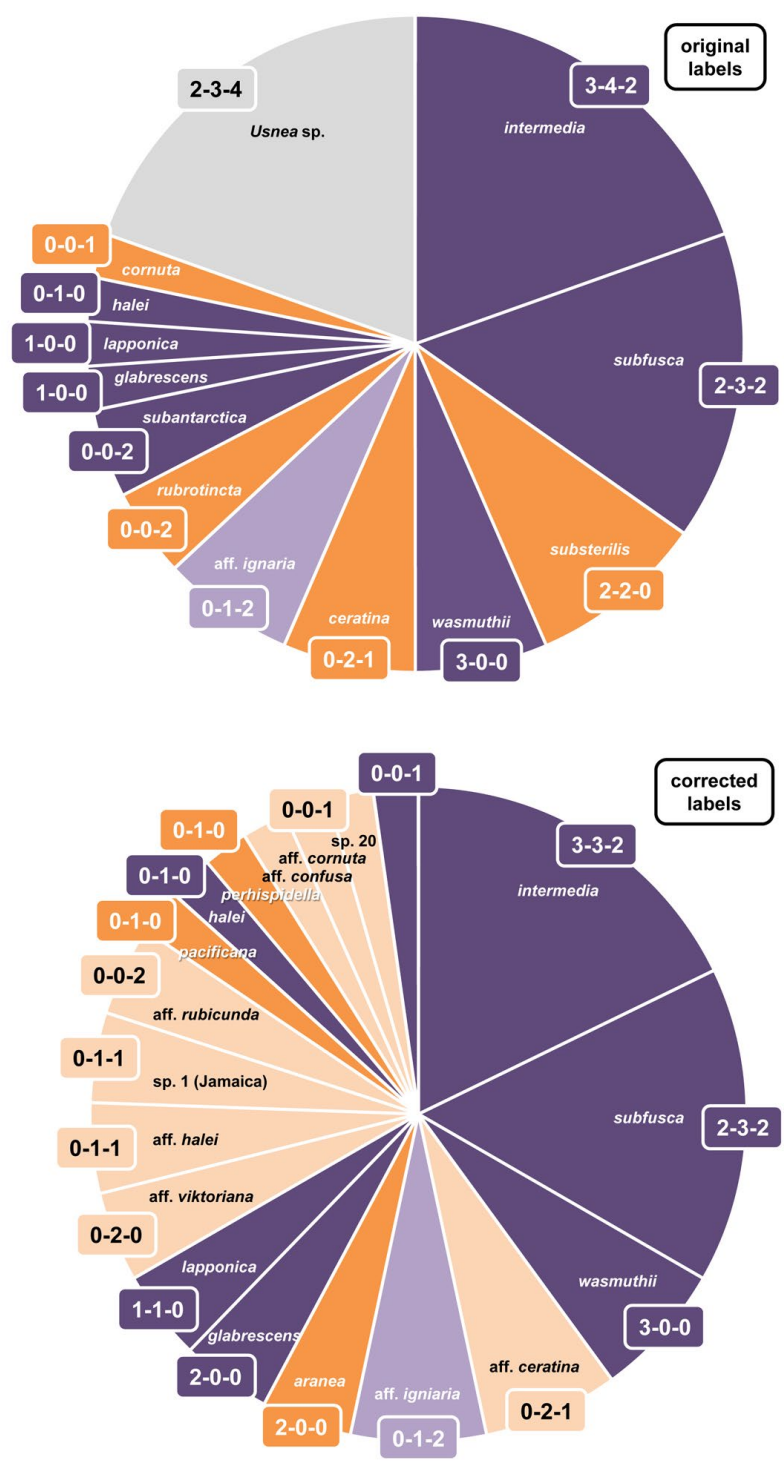

Figure 3. Comparison of NCBI BLASTn results between identifications resulting from the original labels and the corrected labels provided by Lücking et al. (2020c). Each section represents a name-based identification appearing as best hit for one or more query sequences. The numbers indicate the amount of potential $(\geq 98.5 \%$ ), close (between $97 \%$ and $98.5 \%)$ and distant $(<97 \%)$ matches. Purple = names appearing in both original and corrected labels; orange = names appearing either only among original or among corrected labels; light colors in both cases represent names with qualifiers (cf., aff.).
- DB22608: aff. viktoriana (NCBI revised) $\rightarrow$ aff. fragilescens (local)

- DB22609: aff. intermedia (NCBI revised) $\rightarrow$ aff. barbata (L.) F.H. Wigg. (local)

- DB22625: aff. intermedia (NCBI revised) $\rightarrow$ aff. barbata (local)

- DB22615: aff. subfusca (NCBI revised) $\rightarrow$ aff. silesiaca Motyka (local)

- DB22638: aff. confusa (NCBI revised) $\rightarrow$ tenuicorticata Gerlach et al. (local)

- DB22672: cf. perhispidella (NCBI revised) $\rightarrow$ aff. subpectinata Stirt. (local)

- MON5866: cf. perhispidella (NCBI revised) $\rightarrow$ aff. subpectinata (local)

- MON5335: cf. subfusca (NCBI revised) $\rightarrow$ aff. wasmuthii (local)

- MON5795: aff. ceratina (NCBI revised) $\rightarrow$ aff. rubicunda (local)

Phylogenetic approach. The best-scoring maximum likelihood tree placed the 15 query sequences in 12 distant positions within Usnea s.str. (Fig. 4; Fig. S1). Three pairs of samples clustered together in grades or clades of closely related or perhaps conspecific lineages: DB22672 formed a paraphyletic grade with MON5866; MON6140 and MON6229 formed a monophyletic clade on a long branch with each sequence forming a long internal branch; and DB22609 and DB22625 also formed a monophyletic clade on a long branch (Fig. S1).

As mentioned, the two accessions DB22672 and MON5866 clustered in a paraphyletic grade within an unsupported clade including two accessions from Ecuador (JQ837295) and Peru (JQ837298), originally identified as Usnea cornuta (Truong et al. 2013a) and relabeled $U$. aff. subpectinata by Lücking et al. (2020c). The two query sequences formed a well-supported subclade with the Ecuadorian sample, but from the branch length pattern it was unclear whether one, two, three of four species were involved in this clade. In a three-species solution, MON5866 would be conspecific with the Ecuadorian sample and DB22672 and the Peruvian sample would form distinct species each. In a one- or two-species approach, the two query sequences would be identified as $U$. aff. subpectinata.

The sample MON5795 clustered with support at the base of Usnea dodgei Motyka, but clearly formed a separate lineage, differing in 12 substitutions and two indels, resulting in $97.1 \%$ identity (File S1). MON6230 formed another, entirely separate linage, with no supported relationship to any known species or clade. DB22638 associated closely with an accession from Madeira (JQ837294) originally submitted under the name $U$. brasiliensis (Zahlbr.) Motyka (Truong et al. 2013a) and renamed $U$. tenuicorticata in a recent study, together with two Brazilian accessions on a sister clade (Gerlach et al. 2020; Lücking et al. 2020c). If U. tenuicorticata is accepted in a broad sense, the Colombian sample phylogenetically belongs to that species. MON5349 is another specimen that was found grouping with an existing clade, originally labeled Usnea sp. 4 and formally named $U$. aranea 
Table 3. Local (BioEdit) BLASTn results for the 15 query ITS sequences using the 'Usnea ITS Barcoding Release 1.0' provided by Lücking et al. (2020c). For each query sequence, the three best hits (based on maximum score) are given, plus up to three additional hits with high percentage identity. MS = Maximum score; PI = Percentage identity; Inferred ID = most likely identification based on the highest percentage identity and precision of the reference ID.

\begin{tabular}{|c|c|c|c|c|}
\hline Query & Local BLASTn hits (string) & MS & PI & Inferred ID \\
\hline \multirow[t]{6}{*}{ DB22576 } & Usnea_wasmuthii-2_MK812232_Norway_ID-O-L-198061 & 1021 & $99.8 \%$ & wasmuthii \\
\hline & Usnea_wasmuthii-3_MK812501_Norway_ID-O-L-197890 & 1013 & $99.6 \%$ & \\
\hline & Usnea_wasmuthii-1_AB051676_Japan_ID-Ohmura-3821 & 997 & $99.8 \%$ & \\
\hline & Usnea_wasmuthii-1_JN086331_Estonia_ID-was-02 & 993 & $\underline{100 \%}$ & \\
\hline & Usnea_wasmuthii-1_JN086334_England_ID-was-05 & 993 & $\underline{100 \%}$ & \\
\hline & Usnea_wasmuthii-1_JN086337_England_ID-was-09 & 993 & $\underline{100 \%}$ & \\
\hline \multirow[t]{6}{*}{ DB22608 } & Usnea_fragilescens_MK812021_Norway_ID-O-L-200604 & 981 & $98.8 \%$ & aff. fragilescens \\
\hline & Usnea_aff-fragilescens-1_JQ837309_Bolivia_ID-119 & 971 & $\underline{99.8 \%}$ & \\
\hline & Usnea_aff-fragilescens-1_JQ837310_Bolivia_ID-96 & 955 & $\underline{99.4 \%}$ & \\
\hline & Usnea_fragilescens_JN943519_Scotland_ID-EDNA09-02354 & 932 & $99.0 \%$ & \\
\hline & Usnea_fragilescens_JN943525_Scotland_ID-EDNA09-02346 & 932 & $99.0 \%$ & \\
\hline & Usnea_fragilescens_JN943524_Scotland_ID-EDNA09-02347 & 932 & $99.0 \%$ & \\
\hline \multirow[t]{3}{*}{ DB22609 } & Usnea_barbata-2_KX132929_Switzerland_ID-LIFU020-16 & 846 & $95.8 \%$ & aff. barbata \\
\hline & Usnea_intermedia-2_KX132919_Switzerland_ID-LIFU010-16 & 846 & $95.8 \%$ & \\
\hline & Usnea_aff-viktoriana-3_MK812140_Norway_ID-O-L-184699 & 839 & $95.6 \%$ & \\
\hline \multirow[t]{4}{*}{ DB22615 } & Usnea_subfusca_MG262534_USA_Lendemer-46309 & 912 & $97.7 \%$ & aff. silesiaca \\
\hline & Usnea_dasopoga_MK812173_Norway_ID-O-L-196273 & 910 & $97.5 \%$ & \\
\hline & Usnea_wasmuthii-2_MK812232_Norway_ID-O-L-198061 & 902 & $97.3 \%$ & \\
\hline & Usnea_aff-silesiaca_JQ837331_Ecuador_ID-88 & 900 & $\underline{98.2 \%}$ & \\
\hline \multirow[t]{3}{*}{ DB22625 } & Usnea_barbata-2_KX132929_Switzerland_ID-LIFU020-16 & 862 & $96.2 \%$ & aff. barbata \\
\hline & Usnea_intermedia-2_KX132919_Switzerland_ID-LIFU010-16 & 862 & $96.2 \%$ & \\
\hline & Usnea_aff-viktoriana-3_MK812140_Norway_ID-O-L-184699 & 854 & $96.0 \%$ & \\
\hline \multirow[t]{4}{*}{ DB22638 } & Usnea_tenuicorticata_JQ837294_Madeira_ID-44 & 965 & $\underline{100 \%}$ & tenuicorticata \\
\hline & Usnea_spec_MT553315_Jamaica_JAM-159 & 924 & $97.7 \%$ & \\
\hline & Usnea_aff-cornuta-1_LC479123_Japan_ID-TNS-YO10417 & 912 & $97.5 \%$ & \\
\hline & Usnea_tenuicorticata_MF669811_Brazil_ID-11BR & 906 & $\underline{98.8 \%}$ & \\
\hline \multirow[t]{8}{*}{ DB22671 } & Usnea_pacificana_JN086328_Estonia_ID-subs-01 & 985 & $99.8 \%$ & pacificana \\
\hline & Usnea_pacificana_JN086286_Estonia_ID-dip-05 & 985 & $99.8 \%$ & \\
\hline & Usnea_glabrescens_AB051639_Japan_ID-Ohmura-3824B & 981 & $99.2 \%$ & \\
\hline & Usnea_aff-fulvoreagens-1_AB051638_Japan_ID-Ohmura-2906 & 973 & $99.0 \%$ & \\
\hline & Usnea_pacificana_JN943554_Scotland_ID-EDNA09-01568 & 965 & $\underline{99.8 \%}$ & \\
\hline & Usnea_pacificana_FR799052_Scotland_ID-EDNA09-01568 & 965 & $99.8 \%$ & \\
\hline & Usnea_aff-fulvoreagens-1_KU352691_USA_ID-WW-073 & 957 & $99.6 \%$ & \\
\hline & Usnea_aff-fulvoreagens-1_KU352706_USA_ID-WW-142 & 957 & $99.6 \%$ & \\
\hline \multirow[t]{6}{*}{ DB22672 } & Usnea_aff-dasaea-1_AB051056_Japan_ID-Ohmura-2842 & 916 & $97.7 \%$ & aff. subpectinata \\
\hline & Usnea_spec-4-Buckley_KM369390_New-Zealand_ID-FNO40 & 910 & $97.1 \%$ & \\
\hline & Usnea_perhispidella_HQ671307_unknown_ID-Hur-TW090007 & 910 & $97.3 \%$ & \\
\hline & Usnea_subpectinata-2_MF669884_Brazil_ID-42BR & 892 & $\underline{98.1 \%}$ & \\
\hline & Usnea_subpectinata-2_MF669836_Brazil_ID-114BR & 890 & $\underline{98.1 \%}$ & \\
\hline & Usnea_subpectinata-2_MF669834_Brazil_ID-112BR & 890 & $\underline{98.1 \%}$ & \\
\hline \multirow[t]{3}{*}{ MON5335 } & Usnea_wasmuthii-2_MK812232_Norway_ID-O-L-198061 & 934 & $97.7 \%$ & aff. wasmuthii \\
\hline & Usnea_subfusca_MG262534_USA_Lendemer-46309 & 928 & $97.7 \%$ & \\
\hline & Usnea_intermedia-1_KX132920_Switzerland_ID-LIFU011-16-versA & 928 & $97.7 \%$ & \\
\hline \multirow[t]{3}{*}{ MON5349 } & Usnea_spec_MT553280_Jamaica_JAM-053 & 989 & $98.8 \%$ & aranea \\
\hline & Usnea_spec_MT553285_Jamaica_JAM-060 & 979 & $99.6 \%$ & \\
\hline & Usnea_aranea_JQ837293_Ecuador_ID-121 & 979 & $100 \%$ & \\
\hline \multirow[t]{5}{*}{ MON5795 } & Usnea_aff-rubicunda-6_DQ232664_South-Korea_ID-Hur-50347 & 866 & $96.0 \%$ & aff. rubicunda \\
\hline & Usnea_aff-rubicunda-6_LC479125_Japan_ID-TNS-YO10300 & 866 & $96.0 \%$ & \\
\hline & Usnea_rubrotincta_FJ494951_Taiwan_ID-Li354 & 858 & $95.8 \%$ & \\
\hline & Usnea_rubicunda_JN086323_England_ID-rub-02 & 854 & $96.4 \%$ & \\
\hline & Usnea_rubicunda_JN086322_England_ID-rub-01 & 854 & $96.4 \%$ & \\
\hline \multirow[t]{6}{*}{ MON5866 } & Usnea aff-subpectinata_JQ837295_Ecuador_ID-133 & 969 & $99.6 \%$ & aff. subpectinata \\
\hline & Usnea_perhispidella_HQ671307_unknown_ID-Hur-TW090007 & 934 & $97.9 \%$ & \\
\hline & Usnea_aff-dasaea-1_AB051056_Japan_ID-Ohmura-2842 & 924 & $97.9 \%$ & \\
\hline & Usnea_aff-subpectinata_JQ837298_Peru_ID-28 & 922 & $\underline{98.3 \%}$ & \\
\hline & Usnea_subpectinata-2_MF669884_Brazil_ID-42BR & 908 & $98.6 \%$ & \\
\hline & Usnea_subpectinata-2_MF669836_Brazil_ID-114BR & 906 & $98.6 \%$ & \\
\hline
\end{tabular}


Table 3. Continued.

\begin{tabular}{|c|c|c|c|c|}
\hline Query & Local BLASTn hits (string) & MS & PI & Inferred ID \\
\hline \multirow{5}{*}{ MON6140 } & Usnea_subpectinata-2_MF669834_Brazil_ID-112BR & 906 & $98.6 \%$ & \multirow{5}{*}{ Usnea $\mathrm{sp}}$. \\
\hline & Usnea_subpectinata-2_MF669840_Brazil_ID-119BR & 906 & $98.6 \%$ & \\
\hline & Usnea_spec_MT553302_Jamaica_JAM-081 & 745 & $93.7 \%$ & \\
\hline & Usnea_barbata-2_KX132929_Switzerland_ID-LIFU020-16 & 712 & $92.5 \%$ & \\
\hline & Usnea_intermedia-2_KX132919_Switzerland_ID-LIFU010-16 & 712 & $92.5 \%$ & \\
\hline \multirow[t]{3}{*}{ MON6229 } & Usnea_spec_MT553302_Jamaica_JAM-081 & 892 & $96.7 \%$ & \multirow[t]{3}{*}{ Usnea sp. } \\
\hline & Usnea_barbata-2_KX132929_Switzerland_ID-LIFU020-16 & 841 & $95.4 \%$ & \\
\hline & Usnea_intermedia-2_KX132919_Switzerland_ID-LIFU010-16 & 841 & $95.4 \%$ & \\
\hline \multirow[t]{3}{*}{ MON6230 } & Usnea_aff-ceratina_KY033353_USA_ID-Lendemer-46119 & 914 & $97.1 \%$ & \multirow[t]{3}{*}{ aff. ceratina } \\
\hline & Usnea_spec_MT553305_Jamaica_JAM-085 & 910 & $96.9 \%$ & \\
\hline & Usnea_halei_MG252375_USA_ID-46374 & 906 & $97.1 \%$ & \\
\hline
\end{tabular}

(Truong et al. 2013a; Truong \& Clerc 2016). Phylogenetically, the Colombian sample forms part of that taxon.

The sample DB22608 clustered at the base of the Usnea fragilescens clade, which consists of $U$. fragilescens s.str. from Europe and a basal grade from Bolivia apparently representing a separate species (Lücking et al. 2020c). The Colombian sample phylogenetically forms part of this small grade. An intriguing result was found for the two samples MON6140 and MON6229, both from the same area in southern Colombia and both forming a strongly supported clade on a long branch, but each sample also having a long internal branch (Fig. S1). The clade was sister to an accession representing U. subrubicunda P. Clerc (JQ837332; Truong et al. 2013a), but that relationship was not supported. DB22615 clustered with support with an accession from Ecuador (JQ837331) originally identified as U. silesiaca (Truong et al. 2013a), but not belonging to that species and therefore relabeled $U$. aff. silesiaca by Lücking et al. (2020c). The latter sequence contains a number of odd base calls which could explain the longer internal branch (Lücking et al. 2020c), but based on the topology it is also possible that the Colombian and Ecuadorian samples represent two distinct species. In contrast, the two specimens DB22609 and DB22625 formed a fully supported clade in an unsupported sister group relationship to the European Usnea silesiaca s.str., and both can be considered a single species.

DB22576 clustered with the Usnea wasmuthii clade and phylogenetically formed part of that species, whereas MON5335 did not associate with any species or clade (Fig. S1). Finally, DB22671 fell at the base of a complex formed by $U$. fulvoreagens (Räsänen) Räsänen, $U$. glabrescens and U. pacificana, without support, close to a basal grade of specimens originally identified as $U$. diplotypus Vain., U. glabrescens and U. substerilis, all from Europe (Kelly et al. 2011; Saag et al. 2011), but relabeled $U$. pacificana (Mark et al. 2016; Lücking et al. 2020c). Phylogenetically, the Colombian sample would therefore be identified as $U$. aff. pacificana.

Overall, our phylogenetic analysis associated six samples with sequenced species-level clades and left nine samples orphaned. Compared to the BLAST approaches, phylogenetic analysis revealed another five names as potentially matching targets. Notably, of the seven samples that grouped within existing clades with support, all seven resulted in affinities with South American clades, highlighting a strong geographic signal in the phylogenetic relationships of the Colombian specimens.

BLAST artifacts caused by concatenated reference sequences. Among the original NCBI BLASTn results, we noticed an unusually high number of appearances of the same reference sequence as hit, namely Usnea subfusca (MG262534), which was found among the best hits for no less than eight query sequences (Table 2). In contrast, local BLASTn in BioEdit returned this accession only two times (Table 3 ). Both the high number of appearances in the NCBI BLASTn and the relative 'disappearance' of this accession in the local BLASTn raised suspicion, particularly since the reference accession was used in all BLAST approaches and in the NCBI BLAST it appeared as best hit for various unrelated query sequences (Fig. 4).

The Usnea subfusca accession is an apparently unpublished sequence deposited by K. T. Whittington et al. in 2017. In contrast to other BLAST hits, it represents a complete sequence of the rDNA tandem repeat, i.e., the full nuSSU-ITS-nuLSU gene with a length of 10,050 bases. BLAST results are sensitive to reference and query sequence lengths and especially to substantial differences between the two (Altschul et al. 1990; Camacho et al. 2009; Pearson 2013), and so he hypothesized that the length of this particular accession, encompassing the nuSSU and nuSLU subunits besides the proper ITS, could have caused these peculiar BLAST results. In order to test this, we repeated the local BLASTn approach with the full sequence of 10,050 bases, instead of just using the ITS portion that led the results reported above (see Table 3 ).

Indeed, using only the ITS partition of the Usnea subfusca accession in the local BLAST reference database resulted in just two hits among all 15 query sequences, and only one representing the highest max score (Table 3; DB22615). In contrast, using the full accession produced highest-scoring hits for no less than ten and lower-scoring hits for three additional query sequences relative to this accession (Table 4). This result underlines that reference sequence length strongly influences the scoring parameters even if percentage identity is low, in this case ranging between $92.6 \%$ and $98.4 \%$ (Table 4 ). Unfortunately, the practice of submitting ITS together with the nuSSU or 


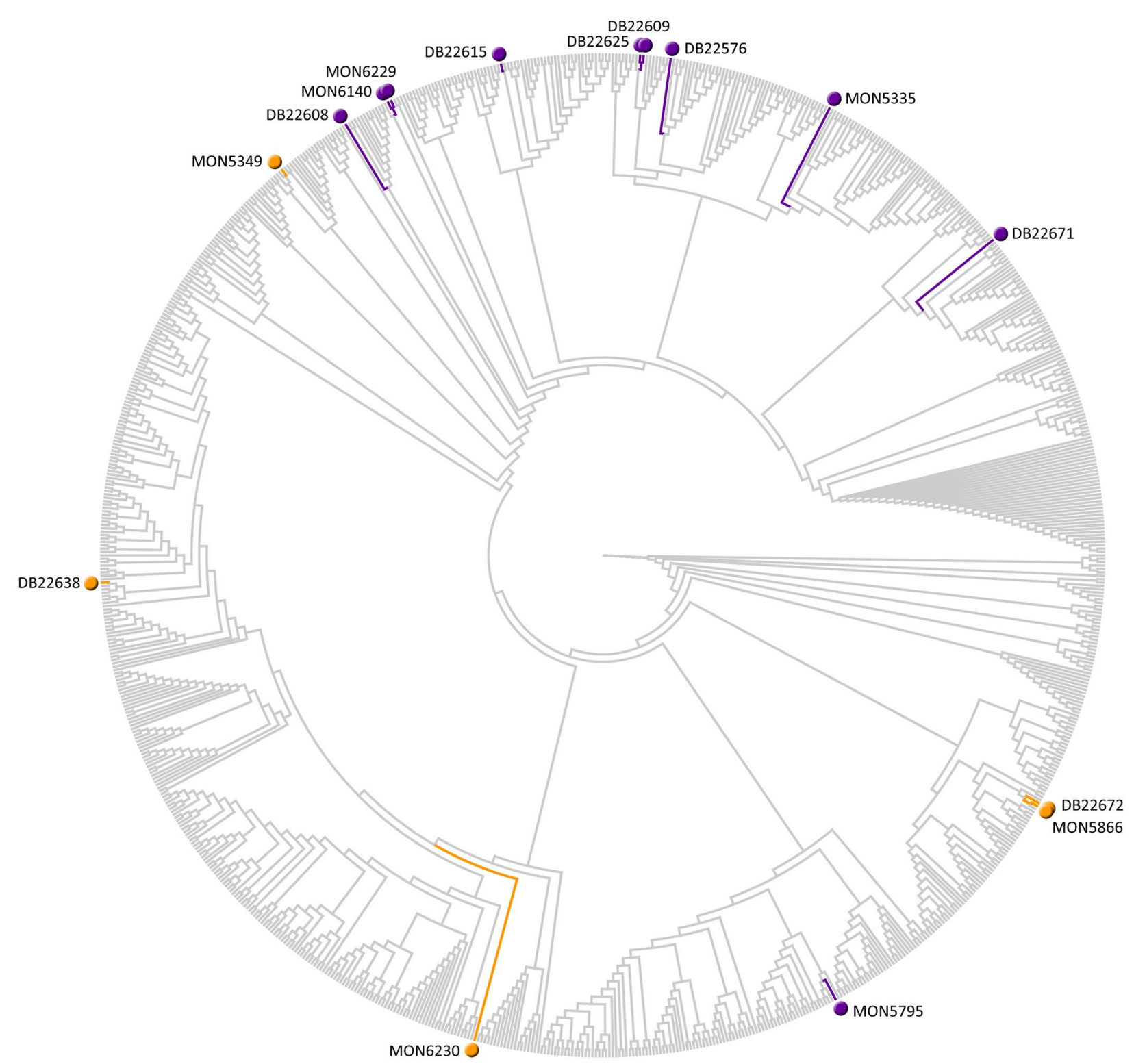

Figure 4. Best-scoring maximum likelihood tree (circle cladogram) of Usnea s.str. based on the ITS barcoding marker. The positions of the Colombian query sequences are highlighted. For exact labels, branch lengths, and bootstrap support, see Fig. S1. The query sequences that had Usnea subfusca (MG262534) as best NCBI BLAST hit are indicated in purple.

nuLSU or both is not rare. For Usnea, we found this for four more Usnea accessions, all apparently from the same study cluster (U. certatina, KY033353; U. halei, MG252375; U. pennsylvanica Motyka, KY114892; U. subscabrosa, MG242037). Notably, three of these also appeared as BLAST hits in our searches (KY033353, MG252375, MG242037), although phylogenetic analysis showed them to be unrelated to our query sequences.

Our findings demonstrate that the practice of concatenated submissions under a single accession should be avoided, as it leads to artifactual, misleading BLAST results when involving the ITS as a fungal barcoding marker (Schoch et al. 2012; Lücking et al. 2020a). The nuclear small subunit (nuSSU), the ITS, and the nuclear large subunit (nuLSU) should be deposited as separate markers, also because they are typically used in a different context, e.g., ITS mostly for species delimitation approaches, and nuSSS and nuLSU for broader phylogenies. Ignoring such concatenated accessions in BLAST searches would not solve this issue, as they do contain the unique information for the ITS for the underlying taxa, which would be missed. Using a filter such as ITSx (Bengtsson-Palme et al. 2013) could potentially address this problem, but it cannot currently be superimposed on NCBI BLAST searches, a problem that needs to be circumvented with local BLAST approaches (Tedersoo et al. 2015).

Integrative taxonomy and comparison of methods. As the last step, we combined the phylogenetic analysis with the phenotypic and chemical characters of the underlying samples using identification tools (Clerc 1987, 2004, 2006, 2007; Gerlach et al. 2017, 2019, 2020; Halonen 2000; Halonen et al. 1998, 1999; Herrera-Campos 2016; Herrera-Campos et al. 2001; Mark et al. 2016; Ohmura 2001, 2012; Randlane et al. 2009; Saag et al. 2011; Truong 
Table 4. Local (BioEdit) BLASTn results for 13 of the 15 query ITS sequences using the 'Usnea ITS Barcoding Release 1.0' provided by Lücking et al. (2020c) after adding the full reference sequence (10,050 bases) of Usnea subfusca (MG262534). Only the best hits down to U. subfusca (MG262534) are given for each query sequence, i.e. ten times the latter appeared as best hit based on max score, once as second (MON5866), fourth (MON5349), and sixth each (MON6230). MS = Maximum score; PI = Percentage identity. Not that max score was generally much higher for this reference sequence than compared to local BLASTn without including this long accession (see Table 3).

\begin{tabular}{|c|c|c|c|}
\hline Query & Local BLASTn hits (string) & MS & PI \\
\hline DB22576 & Usnea_subfusca_MG262534_USA_Lendemer-46309-rDNA-cistron & 1098 & $98.4 \%$ \\
\hline DB22608 & Usnea_subfusca_MG262534_USA_Lendemer-46309-rDNA-cistron & 1070 & $98.2 \%$ \\
\hline DB22609 & Usnea_subfusca_MG262534_USA_Lendemer-46309-rDNA-cistron & 944 & $95.4 \%$ \\
\hline DB22615 & Usnea_subfusca_MG262534_USA_Lendemer-46309-rDNA-cistron & 1063 & $98.0 \%$ \\
\hline DB22625 & Usnea_subfusca_MG262534_USA_Lendemer-46309-rDNA-cistron & 959 & $95.8 \%$ \\
\hline DB22671 & Usnea_subfusca_MG262534_USA_Lendemer-46309-rDNA-cistron & 1066 & $98.0 \%$ \\
\hline MON5335 & Usnea_subfusca_MG262534_USA_Lendemer-46309-rDNA-cistron & 1078 & $98.0 \%$ \\
\hline \multirow[t]{4}{*}{ MON5349 } & Usnea_spec_MT553280_Jamaica_JAM-053 & 989 & $98.8 \%$ \\
\hline & Usnea_spec_MT553285_Jamaica_JAM-060 & 979 & $99.6 \%$ \\
\hline & Usnea_aranea_JQ837293_Ecuador_ID-121 & 979 & $100 \%$ \\
\hline & Usnea_subfusca_MG262534_USA_Lendemer-46309-rDNA-cistron & 938 & $96.1 \%$ \\
\hline MON5795 & Usnea_subfusca_MG262534_USA_Lendemer-46309-rDNA-cistron & 894 & $94.8 \%$ \\
\hline \multirow[t]{2}{*}{ MON5866 } & Usnea_aff-subpectinata_JQ837295_Ecuador_ID-133 & 969 & $99,6 \%$ \\
\hline & Usnea_subfusca_MG262534_USA_Lendemer-46309-rDNA-cistron & 940 & $95.7 \%$ \\
\hline MON6140 & Usnea_subfusca_MG262534_USA_Lendemer-46309-rDNA-cistron & 813 & $92.6 \%$ \\
\hline MON6229 & Usnea_subfusca_MG262534_USA_Lendemer-46309-rDNA-cistron & 942 & $95.3 \%$ \\
\hline \multirow[t]{6}{*}{ MON6230 } & Usnea_aff-ceratina_KY033353_USA_ID-Lendemer-46119 & 914 & $97.1 \%$ \\
\hline & Usnea_spec_MT553305_Jamaica_JAM-085 & 910 & $96.9 \%$ \\
\hline & Usnea_halei_MG252375_USA_ID-46374 & 906 & $97.1 \%$ \\
\hline & Usnea_spec-20_MK010860_Brazil_ID-214376209 & 896 & $96.7 \%$ \\
\hline & Usnea_flammea_MK811847_Norway_ID-O-L-197827 & 890 & $96.5 \%$ \\
\hline & Usnea_subfusca_MG262534_USA_Lendemer-46309-rDNA-cistron & 890 & $95.7 \%$ \\
\hline
\end{tabular}

\& Clerc 2016; Truong et al. 2013a, b; Vareschi 2001) and digital information on types available from JSTOR Global Plants (https://plants.jstor.org; Ryan 2018). Based on this approach, we arrived at the identifications presented and discussed below in the taxonomic section. A name was given to a specimen when it was associated with the clade representing that name according to Lücking et al. (2020c) and the phenotype characters, including medullary chemistry, provided a fit. When no name could be given to a specimen, we employed qualifiers ('cf.', 'aff.') denoting either the most closely related taxon based on the phylogeny or the most similar taxon based on phenotype and medullary chemistry.

When comparing the various approaches, from default NCBI BLAST to local BLAST using a curated reference data set, to phylogenetic analysis, and finally to integrative taxonomy, we found a strongly progressive improvement in the identification results (Fig. 5). Setting the results from the integrative taxonomy as standard (i.e., 100\%), the NCBI BLASTn based on reference sequence identifications as originally submitted performed poorly, leading to only one correct identification ( $7 \%$ success rate). The same BLAST approach, but with corrected identifications provided by Lücking et al. (2020c) offered two taxonomically and three phylogenetically correct identifications, the latter with names that had to be adjusted with integrative taxonomy (see below). Giving one point to taxonomically correct identifications (matching clade and precise name) and half a point to phylogenetically correct identifications (matching clade, but name not resolved), this approach thus had a success rate of $23 \%$ (Fig. 5). Local BLAST using a the curated 'Usnea ITS Barcoding Release 1.0' (Lücking et al. 2020c) doubled the success rate to $47 \%$, whereas with phylogenetic analysis, we obtained a success rate of $80 \%$. However, only integrative taxonomy, i.e., comparing phylogenetic placement with phenotype, resulted in ultimately reliable identifications, although only three of the 15 samples could be given a definite name and the remaining 12 samples represented distinct, yet unnamed species (see below).

Thus, while DNA barcoding might seem a fast track to species identification, integrative taxonomy is still far superior in accuracy and precision. As the example of the immediate correct identification of $U$. wasmuthii and the correct identification of $U$. aranea and $U$. tenuicorticata after correction of reference sequence identifications show, this might eventually change when a large number of species has been sequenced and sequence identifications correctly reflect current taxonomy and nomenclature.

We also found that percentage identity was a better predictor of phylogenetic placement than max score, although the latter is generally used to sort BLAST results (Menlove et al. 2009; Lücking et al. 2020a). In the present case, in only five out of 15 cases the highest scoring hit was congruent with phylogenetic placement, whereas in ten cases, the hit with the highest percentage identity corresponded best to the phylogenetic placement. Among the seven query sequences that clustered with support in an existing clade, only in three instances reference sequences in that clade also appeared among the best BLAST hits (compare Table 2; Fig. S1). This suggests that in the absence of reference sequences corresponding to 


\begin{tabular}{|c|c|c|c|c|c|}
\hline & $\begin{array}{c}\text { NCBI BLASTn } \\
\text { Original labels }\end{array}$ & $\begin{array}{l}\text { NCBI BLASTn } \\
\text { Corrected labels }\end{array}$ & $\begin{array}{l}\text { Local BLASTn } \\
\text { Usnea Release } 1.0\end{array}$ & $\begin{array}{l}\text { Phylogenetic } \\
\text { analysis }\end{array}$ & $\begin{array}{l}\text { Integrative } \\
\text { taxonomy }\end{array}$ \\
\hline BGBM22576 & wasmuthii & wasmuthii & wasmuthï & wasmuthii & wasmuthii \\
\hline MON5349 & Usnea sp. & aranea & aranea & aranea & aranea \\
\hline BGBM22638 & Usnea sp. & aff. confusa & tenuicorticata & tenuicorticata & tenuicorticata \\
\hline BGBM22608 & substerilis & aff. viktoriana & aff. frugilescens & aff. fragilescens & aff. fragilescens \\
\hline BGBM22671 & substerilis & pacificana & pacificana & aff. pacificana & aff. fulvoreagens \\
\hline MON6140 & Usnea $\mathrm{sp}$. & Usnea $\mathrm{sp.} 5$ & Usnea sp. 5 & Usnea sp. 5 & aff. fruticans 1 \\
\hline MON6229 & Usnea sp. & Usnea $\mathrm{sp.} 4$ & Usnea $\mathrm{sp.} 4$ & Usnea $\mathrm{sp.} 4$ & aff. fruticans 2 \\
\hline BGBM22609 & intermedia & intermedia & aff. barbata & Usnea sp. 3 & aff. wasmuthii \\
\hline BGBM22625 & intermedia & intermedia & aff. barbata & Usnea sp. 2 & aff. glabrata \\
\hline MON5335 & subfusca & subfusca & aff. wasmuthii & aff. barbata & aff. barbata \\
\hline MON5795 & ceratina & aff. ceratina & aff. rubicunda & aff. dodgei & aff. dodgei \\
\hline MON6230 & ceratina & aff. ceratina & aff. ceratina & Usnea sp. 1 & Usnea sp. 1 \\
\hline BGBM22672 & Usnea sp. & perhispidella & aff. subpecinata & aff. subpectinata & aff. subpectinata \\
\hline MON5866 & Usnea sp. & perhispidella & aff. subpecinata & aff. subpecinata & aff. concinna \\
\hline BGBM22615 & subfusca & subfusca & aff. silesiaca & aff. silesiaca & aff. columbiana \\
\hline Success rate: & $7 \%$ & $23 \%$ & $47 \%$ & $80 \%$ & $100 \%$ \\
\hline
\end{tabular}

Figure 5. Identification results for the 15 Colombian query samples using different approaches with increasing complexity and precision. Dark purple $=$ precise identifications with fully named species; pale purple $=$ precise identifications with provisionally named species; beige $=$ precise identifications with fully or provisionally named species but with revised identifications when incorporating phenotype; white $=$ imprecise or wrong identifications either caused by reference sequence mislabeling or absence of potential matches $\geq 98.5 \%$.

the same or closely related species, the best BLAST hits may be misleading in terms of phylogenetic relationships and not represent the most closely related sequence in the reference data set. Notably, the three query sequences that unambiguously blasted with the corresponding species in a strict sense (DB22576, DB22671, MON5349) had percentage identity values between $99.3 \%$ and $100 \%$ (Table 2). In comparison, there were three reference sequences (all for DB22671) that had a percentage identity between $98.6 \%$ and $99.3 \%$, but did result as the most closely related sequences in the phylogenetic analysis (compare Table 2 and Fig. S1). This suggests that 98.5\% as default value to define species hypotheses (Abarenkov et al. 2010; Kõljalg et al. 2013, 2019; Irinyi et al. 2015; Jeewon \& Hyde 2016; Nilsson et al. 2019) may be too low and values between $99 \%$ and $99.5 \%$ may be more realistic, a result also found in other studies (Edgar 2018; Lücking et al. 2020c).

Richness prediction. Comparison with the 80 species of Usnea s.lat. reported for Colombia (Sipman \& Aguirre-C. 2016; Lücking et al. 2020c; Moncada et al. 2020) revealed that this barcoding exercise only included two previously reported species that were identified with certainty, namely $U$. aranea and $U$. wasmuthii. A third identification, U. tenuicorticata, represents a new record for Colombia, although material previously reported under the name $U$. cornuta may belong here (see below). Three samples are probably conspecific with taxa reported from Colombia under the names U. columbiana, U. concinna, and $U$. fragilescens, but the Colombian material may not actually represent these species in the strict sense (see below). Three other specimens could represent $U$. fruticans, U. jelskii, and U. setulosa, but these potential identifications could not be confirmed (see below). Thus, if we assume that the 15 Colombian query samples represent 15 different species (see below) and between six and nine correspond to species already reported from the country, between $60 \%$ and $40 \%$ would be new records. By extension, the 80 reported species may represent between $40 \%$ and $60 \%$ of the species of Usnea actually present in Colombia, and we would therefore predict a total of between 133 and 200 species (Fig. 6). This number is not unrealistic given that similarly high figures have been demonstrated for other macrolichen genera such as Cora and Sticta (Moncada et al. 2014; Lücking et al. 2017b) and also considering the fact that most of the known specimens of Usnea reported from the country, including

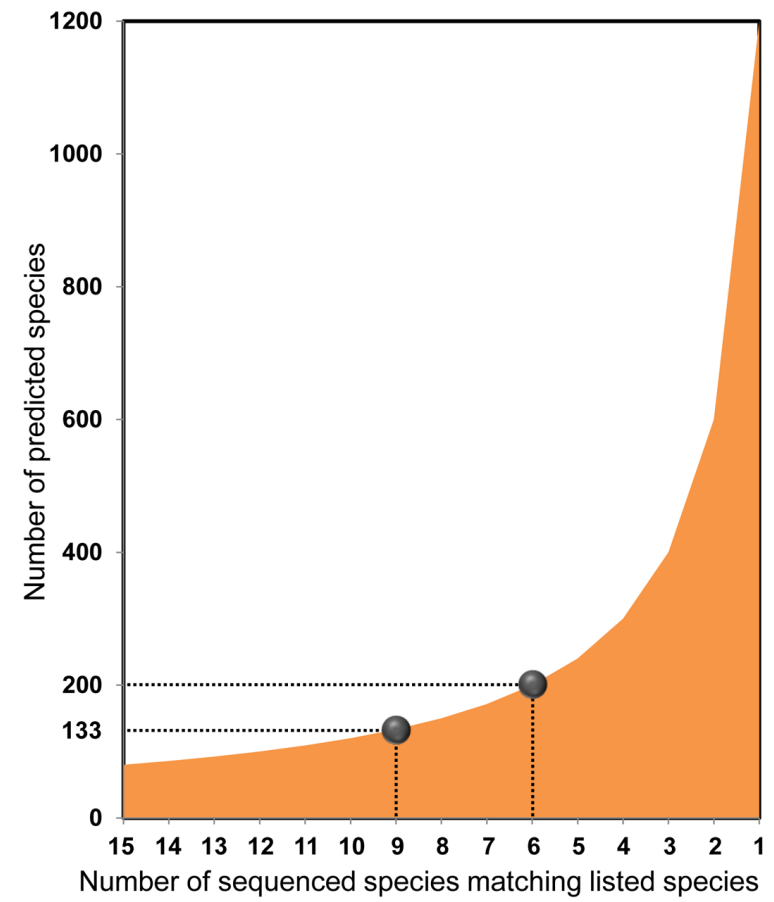

Figure 6. Prediction of the number of species of Usnea in Colombia based on the estimated overlap between reported taxa and those identified in the barcoding exercise. 
12 of the 15 barcoding samples, are from the broader area around Bogotá (Sipman \& Aguirre-C. 2016; Moncada et al. 2020; this paper), whereas much of the country has not been well sampled for lichens in general.

\section{Integrative taxonomy of the barcoded samples}

\section{Usnea aranea Truong \& P. Clerc}

Usnea aranea Truong \& P. Clerc, Lichenologist 48: 77. 2016.

Type: Bolivia, La Paz, Truong 2822 (LPB - holotype; $\mathrm{G}$ - isotype; photograph seen: Truong \& Clerc 2016: 78, fig. 3).

Notes. Usnea aranea is a recently described species, characterized by a shrubby to rarely subpendent thallus with a papillose surface and minute soralia forming isidiomorphs; besides Bolivia (type), Peru, Ecuador, and Venezuela, it was also reported for Colombia, but without sequence data (Truong \& Clerc 2016). The type contains the stictic acid chemosyndrome, but the authors listed four different chemotypes: stictic acid (most specimens), psoromic acid, an unknown depside, or no medullary substances. The type had no sequence data associated with it, but the chemistry of the two sequenced specimens, from Ecuador (JQ837293) and Peru (KP668964), was also given as stictic acid (Truong et al. 2013a; Truong \& Clerc 2016).

ITS-based barcoding using NCBI BLAST of the Colombian sample (MON5349; Rivera \& Salinas 87) gave two potential matches with high percentage similarity from Jamaica (Table 2), but without identification. Using local BLAST with the updated data set identified the Colombian sample as Usnea aranea (Table 3). Phylogenetic analysis placed the sample also within that species, together with the two unidentified, recently submitted accessions from Jamaica (Fig. S1).

The Colombian sample corresponded to the psoromic acid chemotype (Fig. 7) and otherwise agreed well with the Bolivian type (Truong \& Clerc 2016: 78, fig. 3) in morphology, in particular the papillose surface and the numerous soralia with isidiomorphs (Fig. 8). Halonen et al. (1998) listed Usnea nidulans Motyka, a taxon described from Argentina (Motyka 1938) and recently reported for Colombia (Diaz-Escandón et al. 2016) as a shrubby, sorediate species with psoromic acid. The isotype in H (Argentina, Dusén 98; https://plants.jstor.org/ stable/viewer/10.5555/al.ap.specimen.h9508076) agrees well with the Colombian material in the small soralia with scattered isidiomorphs and the numerous, yet irregular fibrils. Truong \& Clerc (2016) did not discuss U. nidulans as a potential name for $U$. aranea, even though they included a psoromic acid chemotype in that species. Since our data resulted in almost identical ITS for the Ecuadorian sample (with stictic acid) and the Colombian specimen (with psoromic acid), the relationship between $U$. aranea and $U$. nidulans should be examined further.

Specimen examined. COLOMBIA. Cundinamarca. Subachoque, Vereda Pantano de Arce, Páramo el Tablazo; $05^{\circ} 00^{\prime} 37.0^{\prime \prime} \mathrm{N}$, $74^{\circ} 12^{\prime} 21.6^{\prime \prime} \mathrm{W}, 3472 \mathrm{~m}$; paramo, on roadbank; 29 October 2016, D. Rivera \& L. Salinas 87 [B (B 60 0200047); UDBC (C-0020645)].

\section{Usnea aff. barbata (L.) F.H. Wigg.}

Usnea barbata (L.) F.H. Wigg., Prim. Fl. Holsat.: 91. 1780.

Type: Dillenius, Historia Muscorum, Tab. XII, fig. 6, 1742; lectotype fide Jørgensen et al. (1994: 372). Sweden, Vastmanland, Nordin s.n. (UPS - epitype fide Jørgensen et al. (1994: 372; digital image seen: https://plants.jstor.org/stable/viewer/10.5555/ al.ap.specimen.g00293431).

Notes. This material (MON5335; Rivera \& Salinas 72) was identified as close to the Usnea barbata-intermedia complex through barcoding (Table 2, 3) and clustered at the base of this complex in the phylogenetic analysis (Fig. 4; Fig. S1). The pendent growth, small soralia and numerous fibrils (Fig. 9) agree with $U$. barbata, whereas the chemistry (stictic acid; Fig. 7; medulla $\mathrm{K}+$ yellow turning orange) differed from the reported chemotypes for this complex (salazinic and protocetraric acid or rarely

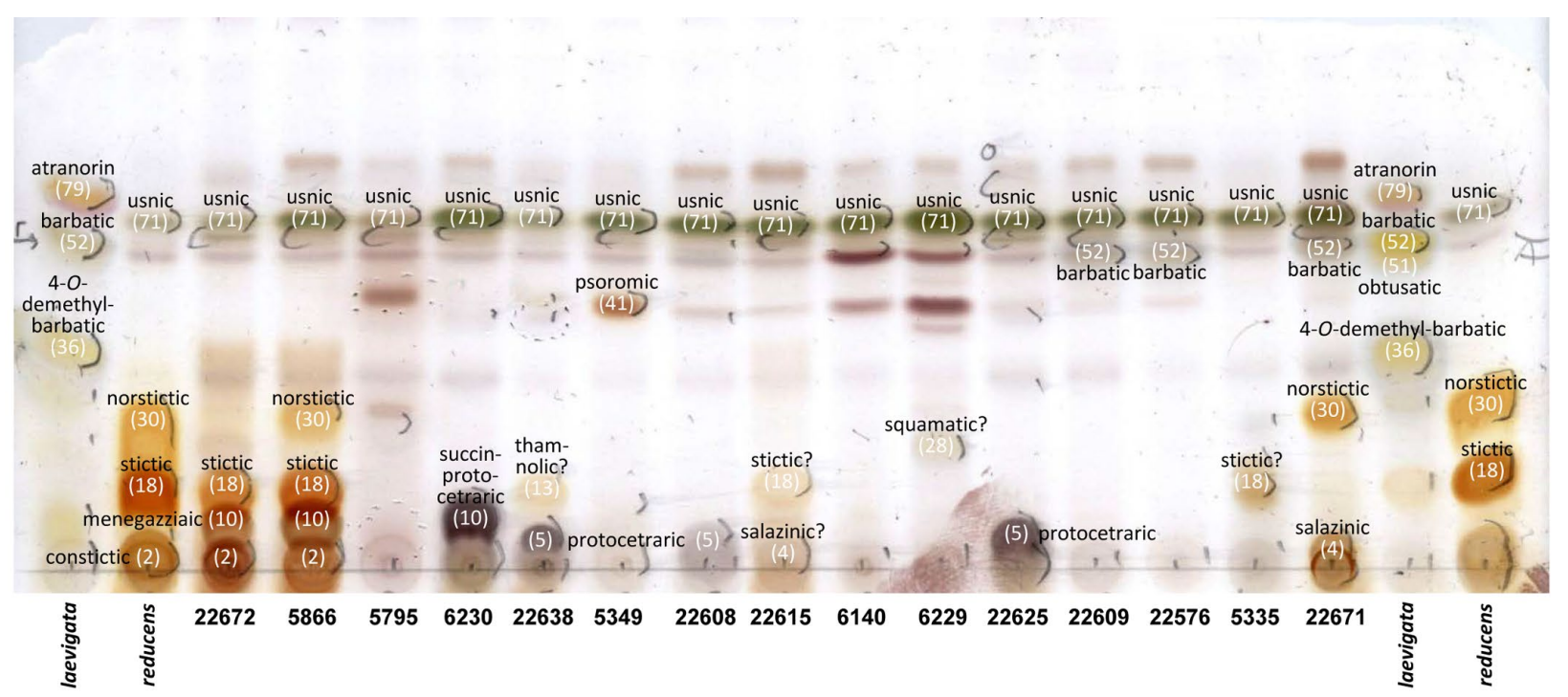

Figure 7. TLC plate (solvent C) of the 15 Usnea samples, using Hypotrachyna laevigata and H. reducens (two different specimens each) as controls. The numbers indicate the Rf values in solvent C according to Huneck \& Yoshimura (1996). 


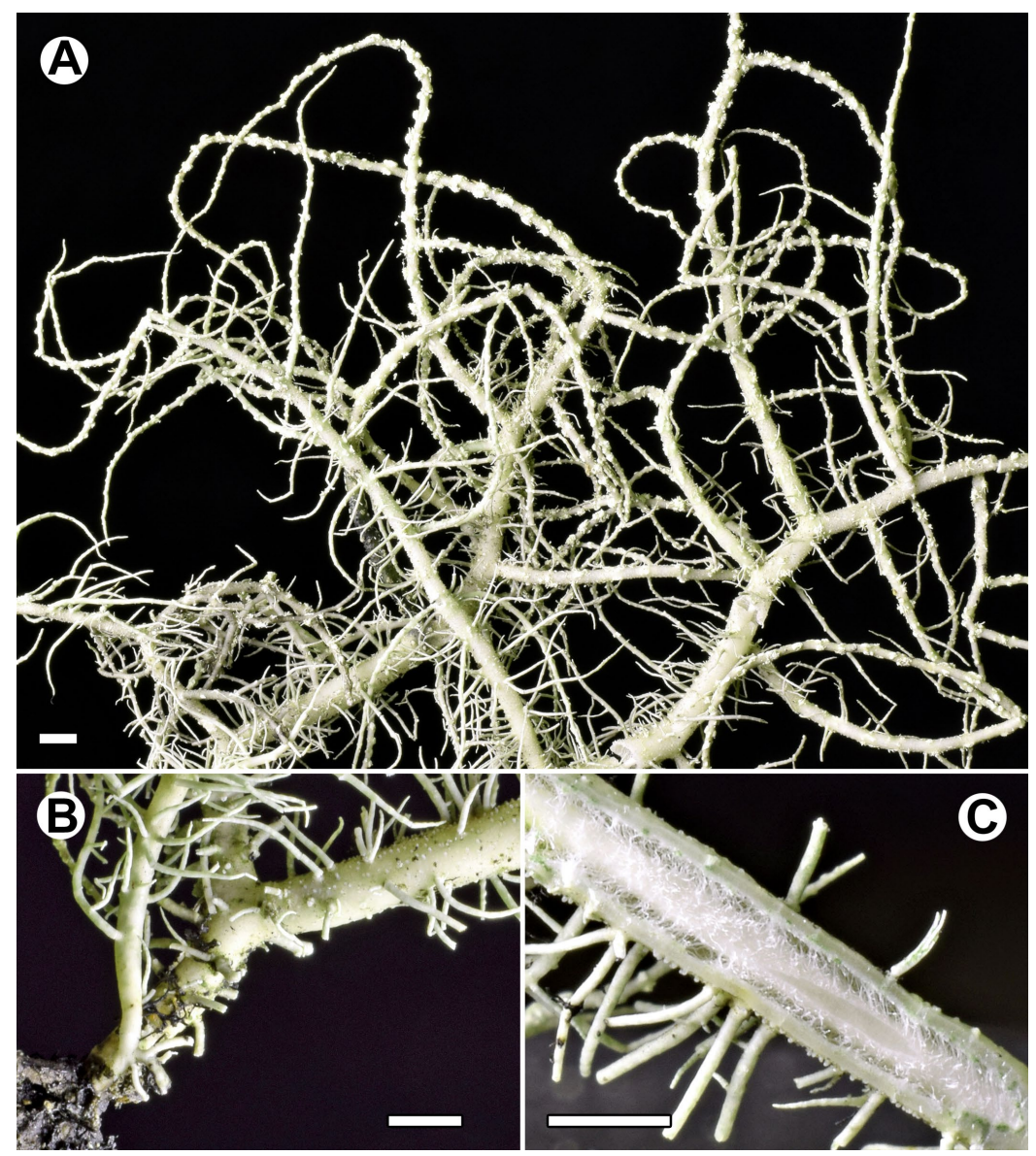

Figure 8. Usnea aranea (MON5349; Rivera \& Salinas 87). A - general habit; B - detail (base); C - section showing CMA. Scale = 1 mm.

no medullary substances; Randlane et al. 2009; Mark et al. 2016).

We were not able to provide a more precise identification for this taxon. According to Truong et al. (2013b), $U$. perhispidella J. Steiner could be a possible fit, but the material does not cluster with that species phylogenetically. Another similar species is U. setulosa Motyka, described from Cuba (Motyka 1938) and also reported from Colombia (Sipman \& Aguirre-C. 2016; RamírezMorán et al. 2016). Two isotypes of $U$. setulosa available on JSTOR Global Plants from S [https://plants.jstor. org/stable/viewer/10.5555/al.ap.specimen.s-f159257; https://plants.jstor.org/stable/viewer/10.5555/al.ap.specimen.s-f152856] agree perfectly with the Colombian material in morphology. According to P. Clerc (pers. comm. 2020), the type material is mixed, containing either stictic or salazinic acid.

Specimen examined. COLOMBIA. Cundinamarca. Subachoque, Vereda Pantano de Arce, Páramo el Tablazo; $05^{\circ} 00^{\prime} 37.0^{\prime \prime} \mathrm{N}$, $74^{\circ} 12^{\prime} 21.6^{\prime \prime} \mathrm{W}, 3472 \mathrm{~m}$; paramo, on roadbank; 29 October 2016, D. Rivera \& L. Salinas 72 [B (B 60 0200046); UDBC (C-0020630)].

\section{Usnea aff. dodgei Motyka}

Usnea dodgei Motyka, Lich. Gen. Usnea Monogr. 2: 572, 610. 1938.

Type: Costa Rica, Cartago, Polakowsky s.n. (LBL - holotype; S - isotype; digital image seen: https://plants.jstor.org/ stable/viewer/10.5555/al.ap.specimen.s-f158993).
Notes. The specimen under study (MON5795; Moncada \& Lücking 11069) had no close match in the barcoding exercise, but clustered with support with material identified as Usnea dodgei, a species described from Costa Rica and widespread in the Neotropics, with a shrubby to subpendent habit, a papillose surface, soredia, and a stictic acid chemistry (Truong et al. 2013b). The sequenced specimens from Brazil produced norstictic and salazinic acid (Gerlach et al. 2019), a rare chemotype according to Truong et al. (2013b), so it is not clear whether they actually represent $U$. dodgei in the strict sense.

The Colombian specimen only produced terpenoids (Fig. 7) in a pattern similar to U. deformis Motyka, but that species additionally contains the stictic acid chemosyndrome (Truong et al. 2013b), whereas depsidones are absent in the Colombian material. Morphologically, the Colombian sample was characterized by a rather robust, subpendent thallus with numerous, conspicuous tubercles and minute soralia formed along the terminal branches (Fig. 10). Truong et al. (2013b) reported several pendent species with chemotypes producing terpenoids only, but none of them fits the Colombian material morphologically.

Specimen examined. COLOMBIA. Cundinamarca, Bogotá, Vereda Pasquilla, near El Carmen; 04 $26^{\prime} 18.5^{\prime \prime} \mathrm{N}, 74^{\circ} 10^{\prime} 29^{\prime \prime} \mathrm{W}$, $3348 \mathrm{~m}$; remnant of altoandine cloud forest, on tree bark; 6 November 2017, B. Moncada \& R. Lücking 11069 [B (B 60 0200048); UDBC (C-0023160)]. 


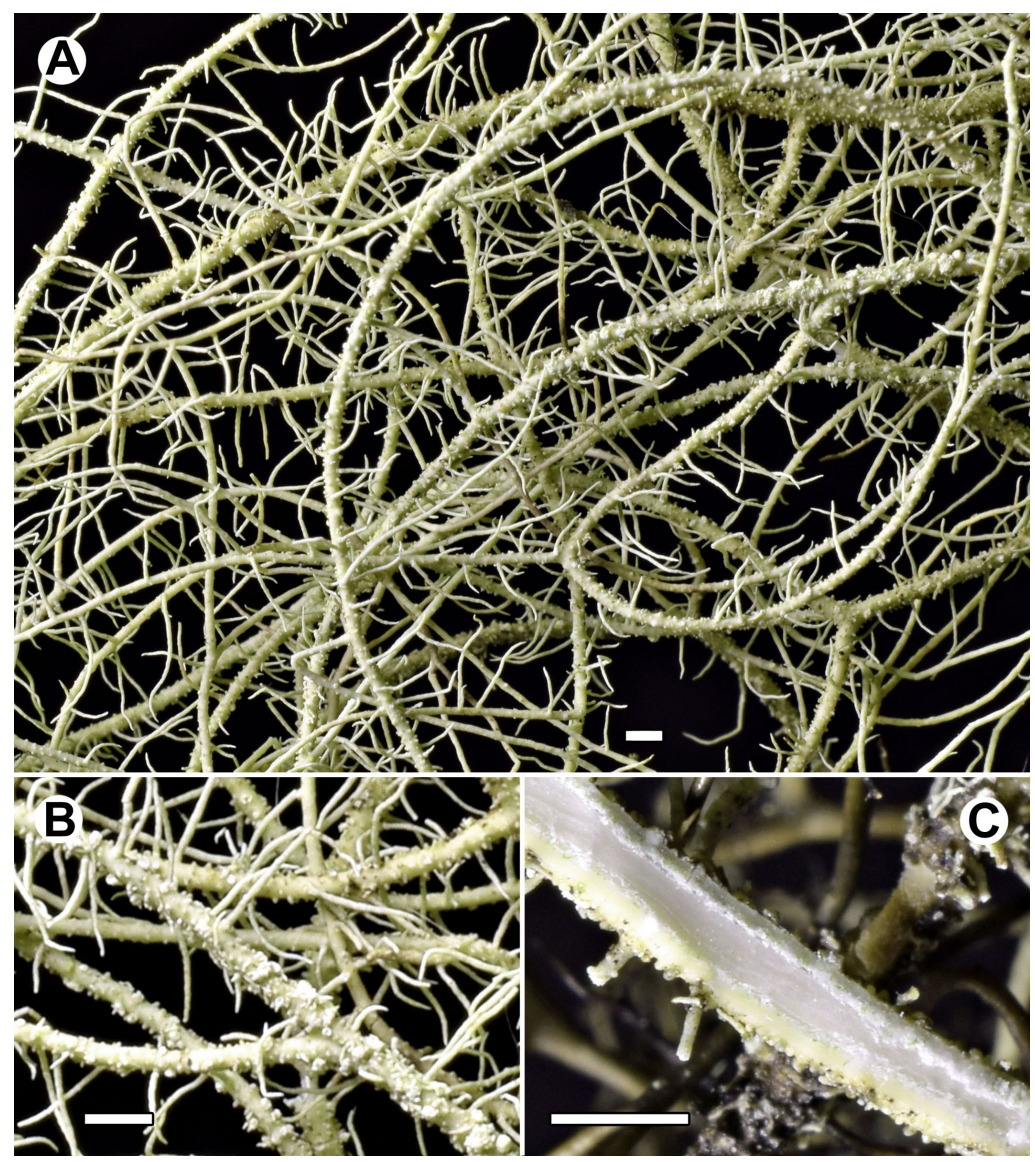

Figure 9. Usnea aff. barbata (MON5335; Rivera \& Salinas 72). A - general habit; B - detail; C - section showing CMA. Scale = 1 mm.

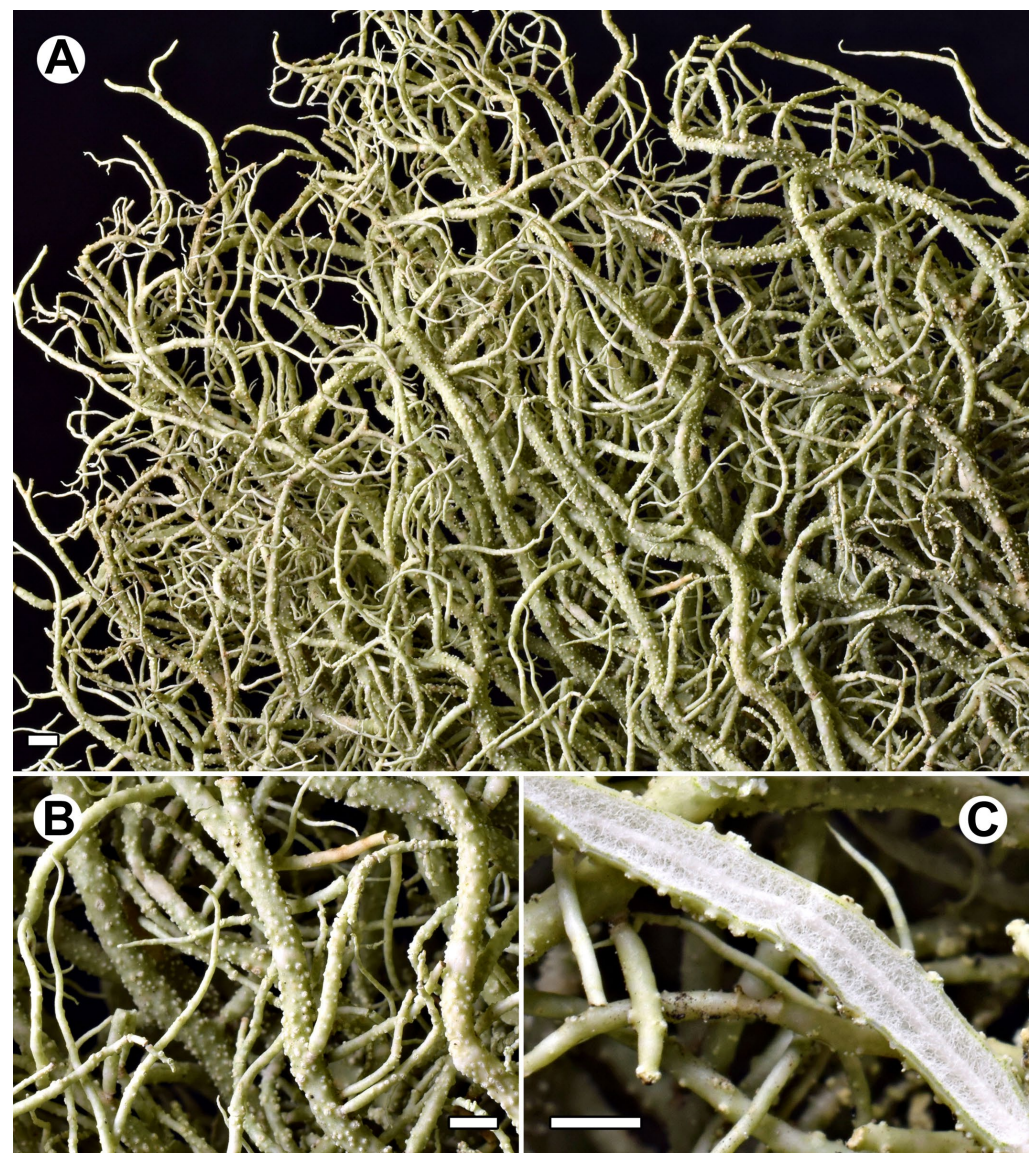

Figure 10. Usnea aff. dodgei (MON5795; Moncada \& Lücking 11069). A - general habit; B - detail; C - section showing CMA. Scale = 1 mm. 


\section{Usnea aff. fragilescens Hav. ex Lynge}

Usnea fragilescens Hav. ex Lynge, Stud. Lich. Fl. Norway: 230. 1921.

Type: Norway, Havaas s.n. (O - lectotype fide Clerc 1987: 491, not seen).

Notes. Usnea fragilescens is characterized by a shrubby to subpendent growth, soralia that become rather large, but remain discrete, and a medullary chemistry with stictic acid (Clerc 1987; Herrera-Campos et al. 2001; Randlane et al. 2009). Two varieties are usually distinguished: var. fragilescens which is typically saxicolous, and var. mollis (Vain.) P. Clerc (Clerc 1987), which is less elongate and more tufted and produces more numerous isidiomorphs. However, given the presumed wide distribution of both morphs (Clerc 1987; Herrera-Campos et al. 2001; Randlane et al. 2009), their recognition at infraspecies level is not appropriate, since one would expect some degree of biogeographic differentiation between infraspecific lineages. Therefore, if the two forms indeed represent different taxa, they should be recognized as separate species. Unfortunately, the combination U. mollis (Neck.) Baumg. already exists in the genus for a different taxon, and the replacement name $U$. malacea Zahlbr. [non $U$. malacea (Stirt.) Zahlbr. E Protousnea malacea (Stirt.) Krog] is illegitimate (Clerc 1987).

Molecular data suggest that Usnea fragilescens is a European species, with North and South American samples forming separate, in part unrelated lineages (Lücking et al. 2020c). The Colombian specimen (DB22608; Moncada \& Lücking 41047a) clustered close to two samples (JQ837309, JQ837310) sequenced from Bolivia (Truong et al. 2013a), all three forming a paraphyletic grade in a supported relationship basal to $U$. fragilescens s.str. (Fig. 4; Fig. S1), but likely representing a different species with deviating chemistry (see Lücking et al. 2020c). While the Colombian sample agreed in the large soralia with $U$. fragilescens, the soralia were heavily covered by isidiomorphs, giving the specimen a peculiar appearance (Fig. 11). The two Bolivian specimens produced salazinic acid (Truong et al. 2013a) and the Colombian sample protocetraric acid (Fig. 7). We were unable to match an existing name to this material.

Specimen examined. COLOMBIA. Bogotá, D.C. Vereda Pasquilla, $2 \mathrm{~km} \mathrm{SW}$ of Pasquilla, along rural access road; $04^{\circ} 25^{\prime} 52^{\prime \prime} \mathrm{N}, 74^{\circ} 10^{\prime} 19^{\prime \prime} \mathrm{W}, 3365 \mathrm{~m}$; disturbed shrubby subparamo remnants bordering pasture, on tree root; 3 December 2015; B. Moncada \& R. Lücking (with D. Cabrera \& J. Muñoz) 41047a [B (B 60 0200039), JBB].

\section{Usnea aff. fruticans Motyka (1) \\ Usnea aff. fruticans Motyka (2)}

Usnea fruticans Motyka, Lich. Gen. Usnea Monogr. 3: 633, 646. 1938. lost).

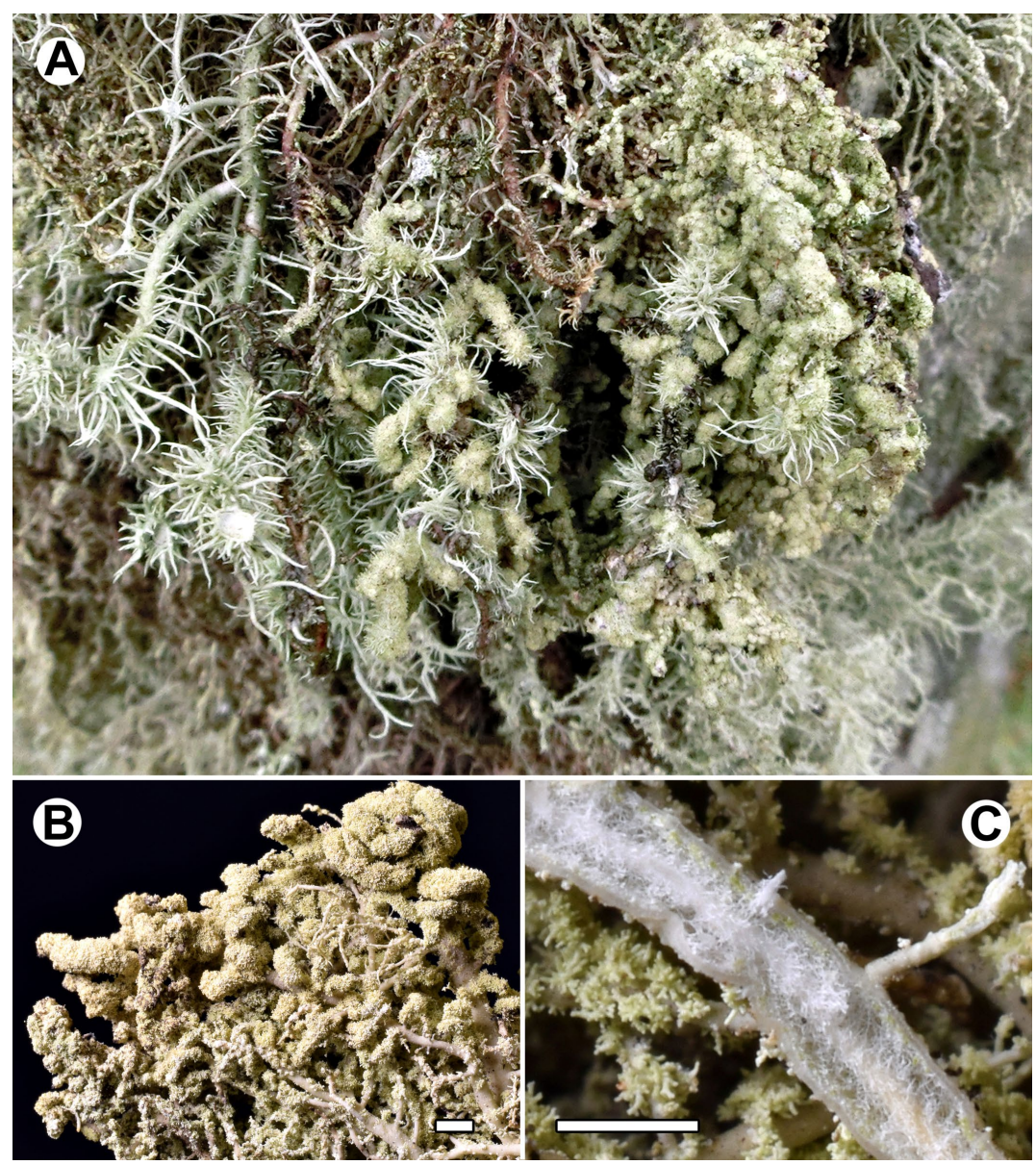

Figure 11. Usnea aff. fragilescens (DB22608; Moncada \& Lücking 41047a). A - general habit; B - detail; C - section showing CMA. Scale =1 mm. 
Notes. This group of two specimens (MON6140; Moncada \& Patiño 11399; MON6229; Moncada \& Patiño 11272a) did not result in close ITS barcoding matches and formed a separate clade on a very long stem branch in the phylogenetic analysis (Fig. 4; Fig. S1). The specimens did not produce soralia or apothecia, but were notable by the very thick basal branches and the dense papillae on the branch surface, plus the occasional formation of isidiomorphs (Figs 12-13). Both specimens produced terpenoids and one also possibly squamatic acid (Fig. 7), although the spot reaction $(\mathrm{C}+$ yellowish, $\mathrm{KC}+$ orange-yellow) does not fit. The two samples differed considerable in their ITS sequence patterns, with 26 substitutions and two indels (97.0\% similarity), indicating that they represented two closely related, yet separate species. This was supported by their different chemistry (Fig. 7) and also the differences in the \%CMA and A/M ratios: $\% \mathrm{CMA}=13 / 24 / 26$ and $\mathrm{A} / \mathrm{M} \approx 1$ in MON6140 and $\% \mathrm{CMA}=17 / 17 / 31$ and $\mathrm{A} / \mathrm{M} \approx 2$ in MON6229 (Figs 12-13), although two specimens is not a statistical sample.

Morphologically both specimens are somehow reminiscent of $U$. jamaicensis which, however, differs in medullary chemistry, producing salazinic (and protocetraric) acid (Herrera-Campos et al. 2001). Also quite similar are U. macrura Vareschi and U. sulphurascens Motyka \& Vareschi, both described from Venezuela (Vareschi 2001). Original material of both taxa available on JSTOR Global Plants from M [https://plants.jstor.org/ stable/viewer/10.5555/al.ap.specimen.m0197296; https:// plants.jstor.org/stable/viewer/10.5555/al.ap.specimen. m0054431] was annotated as $U$. fruticans Motyka by C. Truong, but they appear to represent two separate taxa morphologically, much in accordance with the morphological differences between MON6140 (corresponding more to U. macrura) and MON6229 (corresponding more to U. sulphurascens). We have not seen the type material of $U$. fruticans, but since it was originally reported from Central and South America (Motyka 1938), it is likely conspecific with one of the two lineages. According to the annotations made by $\mathrm{C}$. Truong, the original material of $U$. macrura and $U$. sulphurascens contains unidentified terpenoids, which by extension is then likely also the chemistry of $U$. fruticans and makes MON6140 the best candidate for representing the latter taxon.

Specimens examined. Usnea aff. fruticans 1 (MON6140): COLOMBIA. Putumayo. Santiago, Páramo de los Frailes, right side of road from Pasto to Mocoa; $01^{\circ} 08^{\prime} 36^{\prime \prime} \mathrm{N}, 77^{\circ} 05^{\prime} 49^{\prime \prime} \mathrm{W}$, 2970 m; subparamo dominated by Blechnum stipitellatum and Espeletia pycnophylla; 25 February 2018, B. Moncada \& A. L. Patiño 11399 [B (B 60 0200050), UDBC (C-0023390)]. Usnea aff. fruticans 2 (MON6229): COLOMBIA. Putumayo. San Francisco, Vereda Siberia, surroundings of television station; $01^{\circ} 08^{\prime} 44^{\prime \prime} \mathrm{N}, 76^{\circ} 50^{\prime} 43^{\prime \prime} \mathrm{W}, 2805 \mathrm{~m}$; partially preserved altoandine cloud forest, on bark of Pinus radiata; 24 February 2018 , B. Moncada \& A. L. Patiño 11272a [B (B 60 0200052), UDBC (C-0023632)].

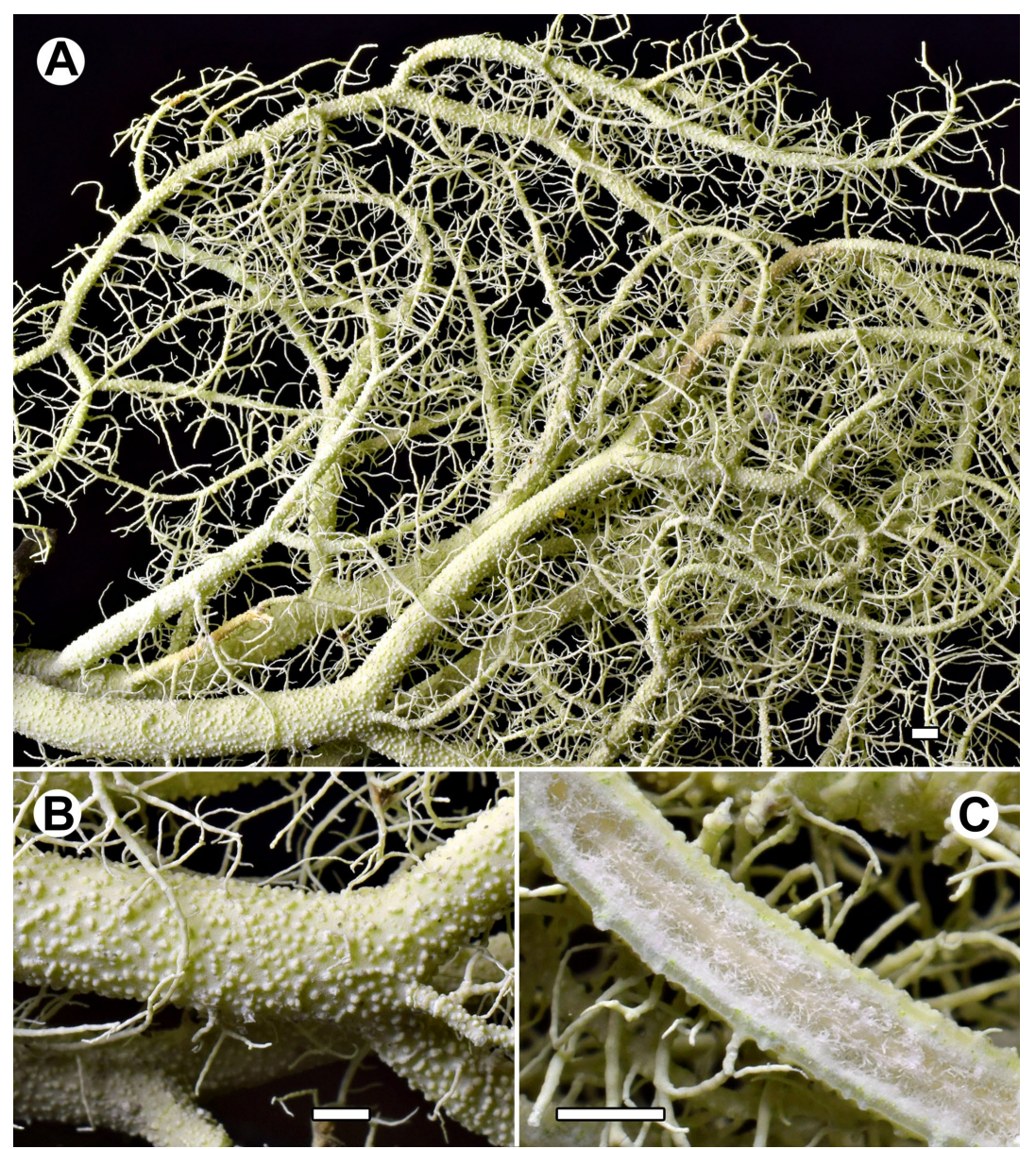

Figure 12. Usnea aff. fruticans 1 (MON6140; Moncada \& Patiño 11399). A - general habit; B - detail; C - section showing CMA. Scale = 1 mm. 


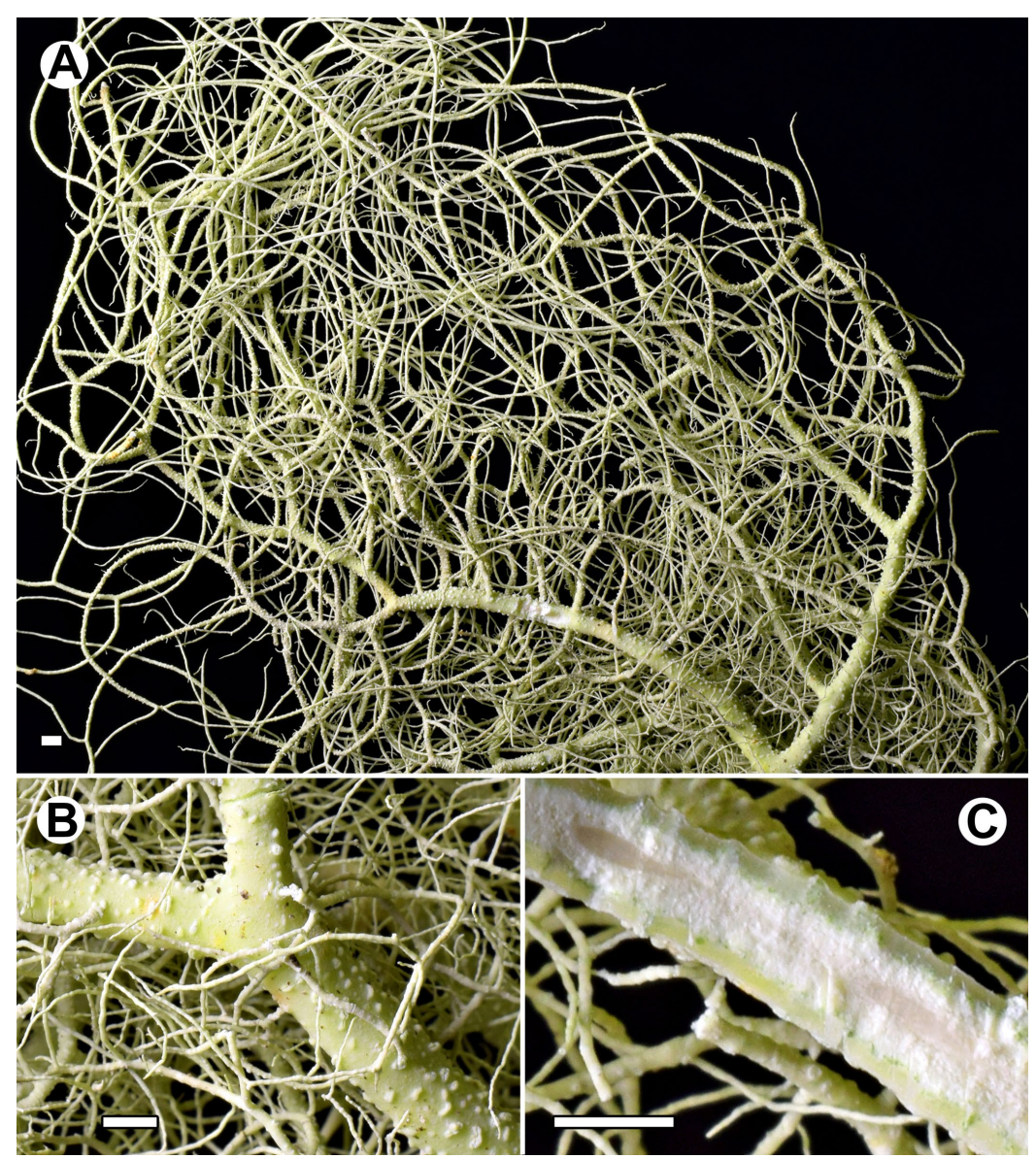

Figure 13. Usnea aff. fruticans 2 (MON6229; Moncada \& Patiño 11272a). A - general habit; B - detail; C - section showing CMA. Scale = 1 mm.

\section{Usnea aff. fulvoreagens (Räsänen) Räsänen}

Usnea fulvoreagens (Räsänen) Räsänen, Lich. Fenn. Exs.: no. 13. 1935 .

Type: Russia, Karelia, Räsänen s.n. (H, specimen 'A' - proposed conserved type fide Halonen \& Ahti 2002: 183; digital image seen: https://plants.jstor.org/stable/viewer/10.5555/al.ap. specimen.h9510932).

Notes. This material (DB22671; Moncada \& Lücking 41099) blasted most closely with Usnea glabrescens and $U$. pacificana based on percentage similarity (Table 2, 3) and clustered at the base of the U. fulvoreagens-glabrescens-pacificana complex (Fig. 4; Fig. S1) as defined by Lücking et al. (2020c). Usnea pacificana was described for a species from the Pacific Northwest (Halonen 2000), with a shrubby to (sub-)pendent habit, punctiform soralia producing isidiomorphs, and a medullary chemistry with squamatic, baeomycesic and barbatic acid. It is similar to $U$. fulvoreagens and $U$. glabrescens, which chiefly differ in chemistry (norstictic with or without stictic, salazinic, and/or protocetraric acid) and can be distinguished from each other by large, eventually excavate (fulvoreagens) vs. punctiform (glabrescens) soralia (Halonen et al. 1998, 1999; Randlane et al. 2009). The Colombian specimen had large soralia (Fig. 14) and a medullary chemistry of norstictic and salazinic acid, with traces of barbatic acid (Fig. 7), thus agreeing best with $U$. fulvoreagens, the only of the three names not appearing in the BLAST exercise (Table 2, 3). However, the specimen appeared phylogenetically distinct from either of the two U. fulvoreagens s.str. subclades, not due to unique substitutions, but because it shared two substitutions with one subclade and five substitutions with the other (File S1). This denotes another shortcoming of the BLAST approach. While this query sequence would not have a best-scoring match in either of the two $U$. fulvoreagens subclades, in a phylogenetic context it would have a $100 \%$ match with the clade as a whole if within-clade sequence variation could be taken into account.

A shrubby, sorediate species with norstictic and salazinic acid described from South America (Chile) and also reported from Colombia is U. jelskii Motyka (1938; Clerc 2004; Sipman \& Aguirre-C. 2016). It forms part of the $U$. cornuta complex (Gerlach et al. 2019). The type produces salazinic and protocetraric acid, but other material has been described as containing norstictic instead of protocetraric acid. The Colombian material is not well-developed and in part attacked by a parasite, but it fits the general morphology of the $U$. cornuta aggregate. Gerlach et al. (2019) reported two other species in that aggregate with norstictic and salazinic acid, $U$. densirostra Taylor and $U$. dodgei, but the Colombian specimen did not cluster with these phylogenetically.

The status and typification of the name Usnea fulvoreagens is unclear. When establishing $U$. fragilescens var. fulvoreagens Räsänen, the author (Räsänen 1931) cited three localities, all in Estonia. According to Halonen et al. (1999), one syntype represented U. subfloridana Stirt., 


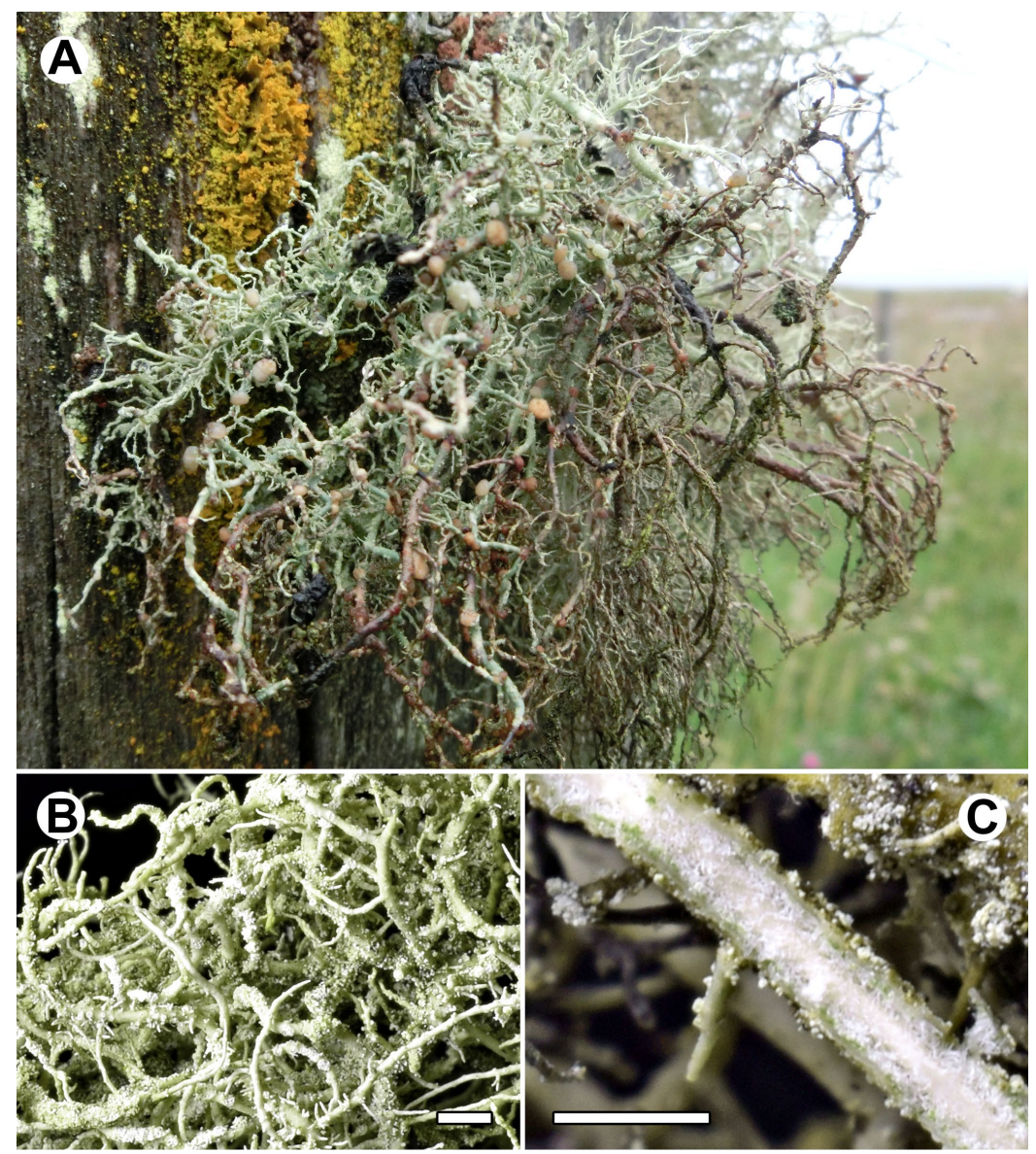

Figure 14. Usnea aff. fulvoreagens (DB22671; Moncada \& Lücking 41099). A - general habit; B - detail; C - section showing CMA. Scale = 1 mm.

whereas the other syntypes could not be located. Halonen \& Ahti (2002) therefore proposed to conserve the name $U$. fragilescens var. fulvoreagens with a conserved type, while at the same time designating the syntype representing $U$. subfloridana as lectotype of $U$. fragilescens var. fulvoreagens, a superfluous designation making the conservation proposal ambiguous (Tavares 2002; Gams 2004). When elevating the taxon to species level, Räsänen (1935) had added localities from Finland; shortly after, he listed further collections from Finland (Räsänen 1939), from an area later annexed by the USSR. One of these latter collections is the one proposed as the conserved type (Halonen \& Ahti 2002). It is, however, unclear whether a conservation proposal is required to designate this material as type. The proposed conserved type had been collected by Räsänen in 1923, eight years before he formally established the name. The label bears both the names $U$. fulvoreagens and $U$. fragilescens var. fulvoreagens (as 'Syn.') in Räsänen's handwriting, implying that he identified the specimen after 1935, likely for his later publication (Räsänen 1939). Therefore, although the material had been collected in 1923, it is not possible to argue that Räsänen may have used this material, without citing, when describing $U$. fragilescens var. fulvoreagens, in which case it could have been designated as lectotype (ICN Art. 9.3, 9.4). However, since two of the original syntypes have not yet been found (while the third represents another species), it is technically possible to designate the proposed conserved type as a neotype without a conservation proposal.
Specimen examined. COLOMBIA. Bogotá, D.C. Vereda Pasquilla, $2 \mathrm{~km} \mathrm{SW}$ of Pasquilla, along rural access road; $04^{\circ} 25^{\prime} 52^{\prime \prime} \mathrm{N}, 7^{\circ} 10^{\prime} 19^{\prime \prime} \mathrm{W}, 3365 \mathrm{~m}$; disturbed shrubby subparamo remnants bordering pasture, on tree bark; 3 December 2015; B. Moncada \& R. Lücking (with D. Cabrera \& J. Muñoz) 41099 [B (B 60 0200044), JBB].

\section{Usnea aff. glabrata (Ach.) Vain.}

Usnea glabrata (Ach.) Vain., Ann. Acad. Sci. Fenn., Ser. A 6(7): 7. 1915.

Type: Switzerland, Schleicher 318 (H-ACH 1854A holotype; digital image seen: https://plants.jstor.org/stable/ viewer/10.5555/al.ap.specimen.h9502951).

Notes. This material (DB22625; Moncada \& Lücking $41058 \mathrm{c})$ formed part of a fully supported clade $(100 \%$ bootstrap support) consisting of two specimens (the other being DB22609; Moncada \& Lücking 41048a; see below under Usnea aff. wasmuthii), with minor differences in the base patterns between the two samples in two positions (File S1). Despite their close relationship, the two specimens were morphologically and chemically distinct (Figs 7, 15, 21), DB22625 had a shrubby habit with slightly constricted branch bases, a smooth surface lacking papillae, medium-sized soralia becoming excavate, no isidiomorphs and scarce fibrils, and produced protocetraric acid (Fig. 7). The specimen was also attached by an unidentified lichenicolous fungus mostly near the base (Fig. 15). The phenotype features would point to U. glabrata (Halonen et al. 1999; Randlane et al. 2009), 


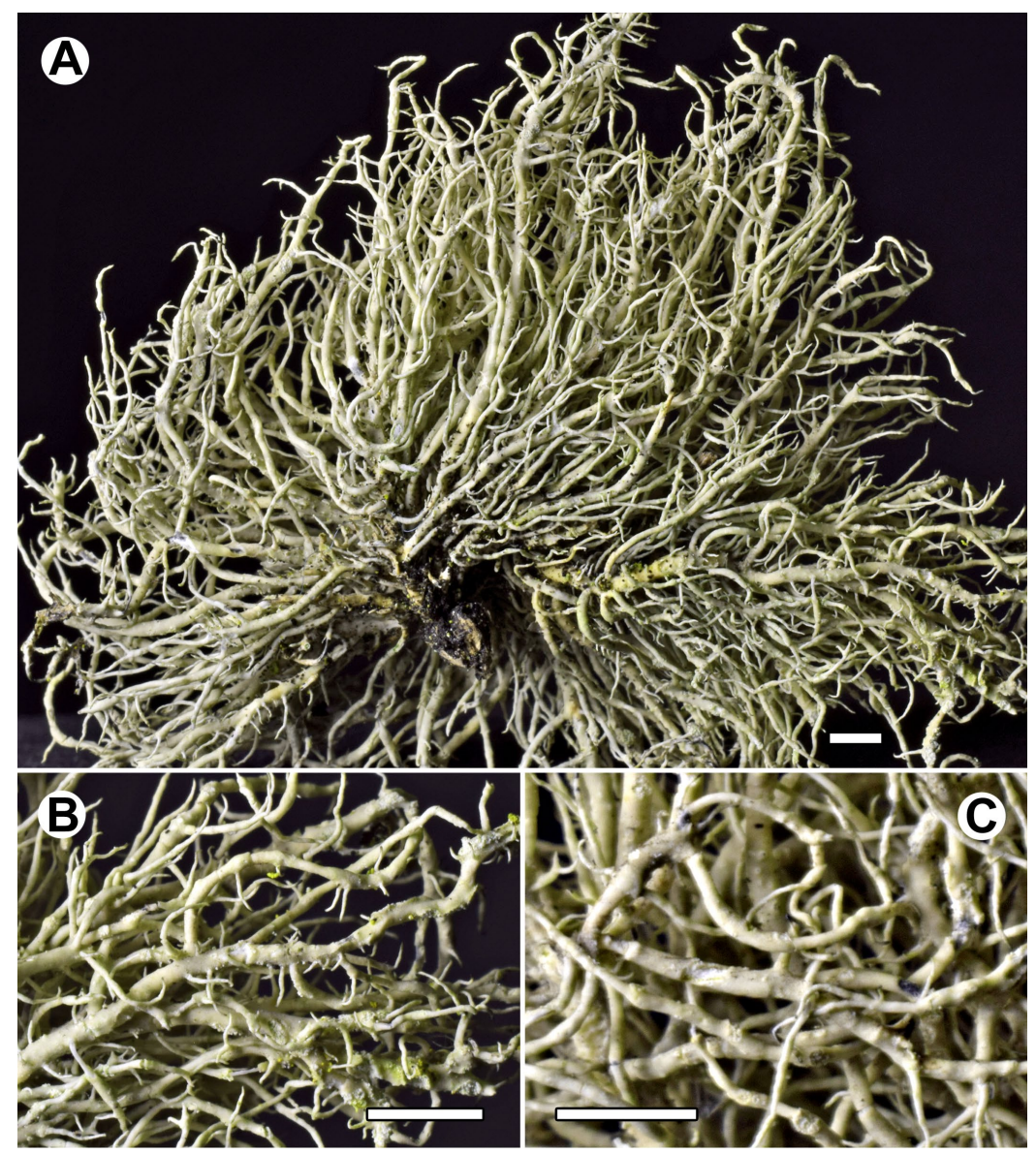

Figure 15. Usnea aff. glabrata (DB22625; Moncada \& Lücking 41058c). A - general habit; B-C - detail. Scale = $1 \mathrm{~mm}$.

but the specimen was not phylogenetically related to the clade containing U. glabrata (Fig. S1).

Specimen examined. COLOMBIA. Bogotá, D.C. Vereda Pasquilla, $2 \mathrm{~km} \mathrm{SW}$ of Pasquilla, along rural access road; $04^{\circ} 25^{\prime} 52^{\prime \prime} \mathrm{N}, 7^{\circ} 10^{\prime} 19^{\prime \prime} \mathrm{W}, 3365 \mathrm{~m}$; disturbed shrubby subparamo remnants bordering pasture, on fence post; 3 December 2015; B. Moncada \& R. Lücking (with D. Cabrera \& J. Muñoz) 41058c [B (B 60 0200042), JBB].

\section{Usnea aff. silesiaca Motyka}

Usnea silesiaca Motyka, Wydawnictwa Muzeum Slaskiego w Katowicach 3(2): 19. 1930.

Type: Poland, Motyka s.n. (LBL - holotype, not seen).

Notes. Usnea silesiaca is a European and North American species distinguished by a shrubby to (sub-)pendent thallus with annular cracks and a blackened base, more or less numerous papillae and fibrils, conspicuous soralia, a thick cortex, thin and compact medulla, and thick axis, and salazinic acid as medullary substance (Clerc 2004; Randlane et al. 2009). A single accession from Ecuador (JQ837331) identified with that name and also producing salazinic acid (Truong et al. 2013a) fell elsewhere in the global ITS tree and did not represent that species (Lücking et al. 2020c).

The Colombian specimen (DB22615; Moncada \& Lücking 41047b) clustered with the Ecuadorian sample with support (Fig. 4; Fig. S1), the differences in individual branch lengths likely caused by aberrant base calls in otherwise uniform sites of the ITS detected in the Ecuadorian sample (Lücking et al. 2020c). The specimen formed numerous, conspicuous soralia particularly along the terminal branches, numerous papillae and fibrils (the latter mostly along subterminal branches), together with a thick cortex, very thin and compact medulla, and thick central axis, and a blackened base (Fig. 16). TLC demonstrated weak spots corresponding to stictic and salazinic acid (Fig. 7). Although generally agreeing with Usnea silesiaca, the Colombian (and Ecuadorian) material is phylogenetically unrelated to the latter.

A potential name for this material is Usnea columbiana Motyka ex Räsänen which, despite its name, was described from Chile (Räsänen 1936). According to Clerc (2006), this is a shrubby species producing soredia, with a black base and with a salazinic acid chemistry. We were able to confirm the morphology of the latter by checking a digital image of the lectotype on JSTOR Global Plants [https://plants.jstor.org/stable/viewer/10.5555/ al.ap.specimen.h9500229]. However, in lieu of sequence data from Chilean material, it remains unclear whether the sequenced specimens from Colombia and Ecuador represent $U$. columbiana.

The report of Usnea columbiana from Colombia (Sipman \& Aguirre-C. 2016) suggests that material identified with that name had previously been collected in that country. However, these authors did not cite voucher material and so it is possible that they included this name in the list in the erroneous assumption that, based on the epithet, 


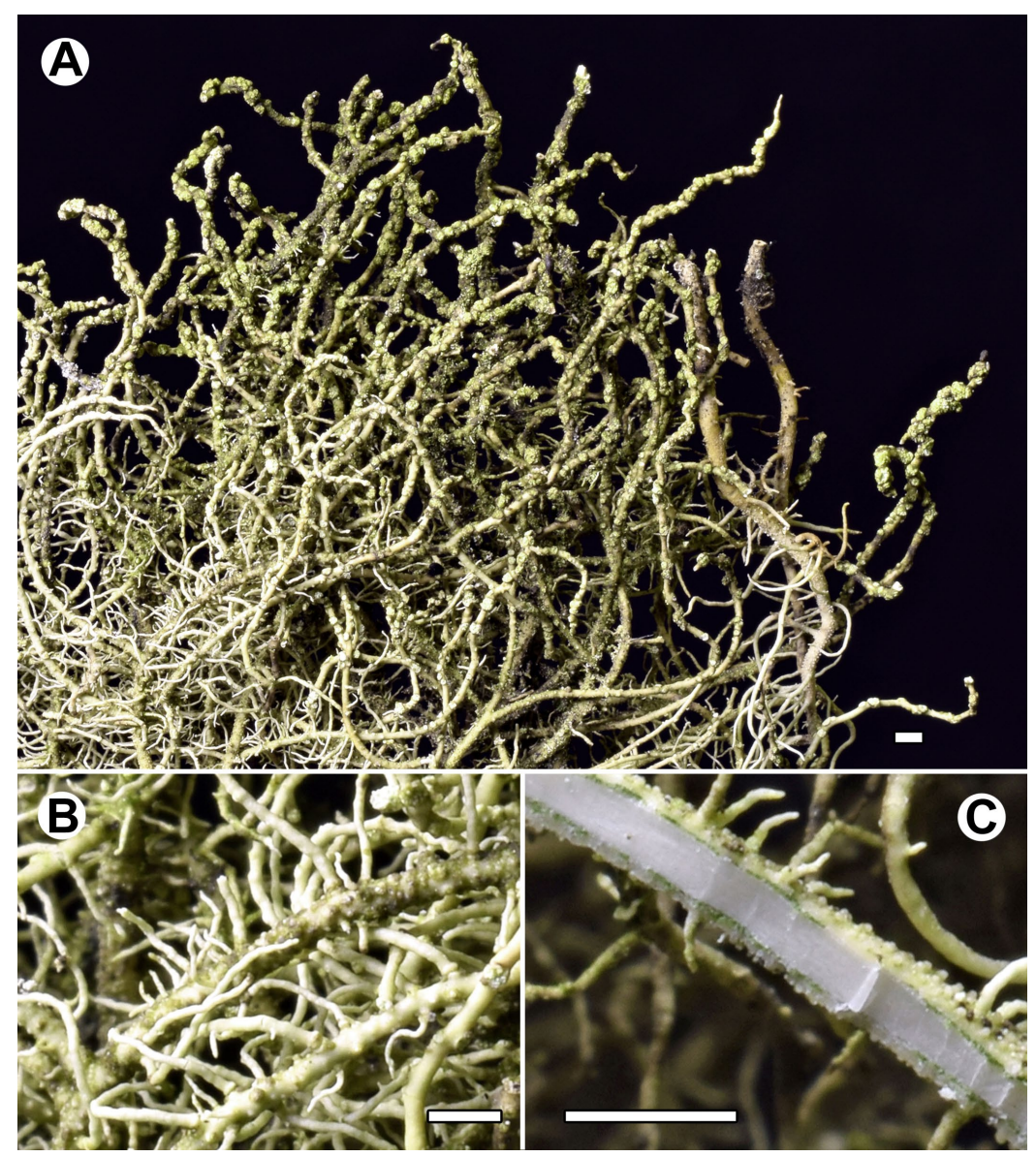

Figure 16. Usnea aff. silesiaca (DB22615; Moncada \& Lücking 41047b). A - general habit; B - detail; C - section showing CMA. Scale = 1 mm.

it had originally been described from Colombia, which is not the case.

Specimen examined. COLOMBIA. Bogotá, D.C. Vereda Pasquilla, $2 \mathrm{~km}$ SW of Pasquilla, along rural access road; $04^{\circ} 25^{\prime} 52^{\prime \prime} \mathrm{N}, 74^{\circ} 10^{\prime} 19^{\prime \prime} \mathrm{W}, 3365 \mathrm{~m}$; disturbed shrubby subparamo remnants bordering pasture, on tree root; 3 December 2015; B. Moncada \& R. Lücking (with D. Cabrera \& J. Muñoz) 41047b [B (B 60 0200040), JBB].

\section{Usnea aff. subpectinata Stirt. 1}

\section{Usnea aff. subpectinata Stirt. 2}

Usnea subpectinata Stirt., Scott. Natural. 6(3): 108. 1881.

Type: Scotland, New Galloway, McAndrew s.n. (BM - lectotype fide Clerc 2004: 80; digital image seen: https://plants. jstor.org/stable/viewer/10.5555/al.ap.specimen.bm001106012).

Notes. Clerc (2004) synonymized Usnea subpectinata with the widespread $U$. cornuta Körb., a shrubby, sorediate taxon (Randlane et al. 2009; Gerlach et al. 2019). The latter has been shown to represent a complex of numerous, in part unrelated lineages, each well-characterized by medullary chemistry (Truong et al. 2013a; Gerlach et al. 2019, 2020; Lücking et al. 2020c). Based on these results, $U$. subpectinata, a species originally described from Great Britain (Stirton 1881), was resurrected for a clade including mostly samples from Brazil, but also one accession from Europe (France; Gerlach et al. 2019, 2020). Two accessions from Ecuador and Peru (JQ837295, JQ837298), originally deposited under the name $U$. cornuta (Truong et al. 2013a), formed a small, separate clade, labeled $U$. aff. subpectinata in Lücking et al. (2020c).

Two samples from Colombia (DB22672; Moncada \& Lücking 41100; MON5866; Moncada et al. 10870) fell into that separate clade, clustering with the accession from Ecuador (JQ837295) with strong support, whereas the accession from Peru (JQ837298) formed an early diverging lineage in that clade without support (Fig. 4; Fig. S1). Both Colombian samples agree with the type of Usnea subpectinata (Clerc 2004) in medullary chemistry, containing three to four (Fig. 7) of the five substances (norstictic, stictic, menegazziaic, constictic, and salazinic acids) reported for the latter (Clerc 2004). The Ecuadorian sample also contained stictic acid, whereas the Peruvian specimen produced galbinic acid (Truong et al. 2013a). Notably, one Colombian specimen (DB22672; Moncada \& Lücking 41100) was densely sorediate with large soralia especially along the terminal branches, as typical for this species complex (Fig. 17), whereas the other (MON5866; Moncada et al. 10870) was apotheciate (Fig. 18).

It is currently unclear whether this northern Andean clade represents a single or perhaps up to four species. At least the Peruvian sample, with deviating chemistry and lack of support as part of this clade, appears to be a separate taxon. The remaining three samples contain two sorediate and one apotheciate specimen and are not homogeneous phylogenetically. The ITS-based identity matrix between the four accessions (Table 5) would separate the 

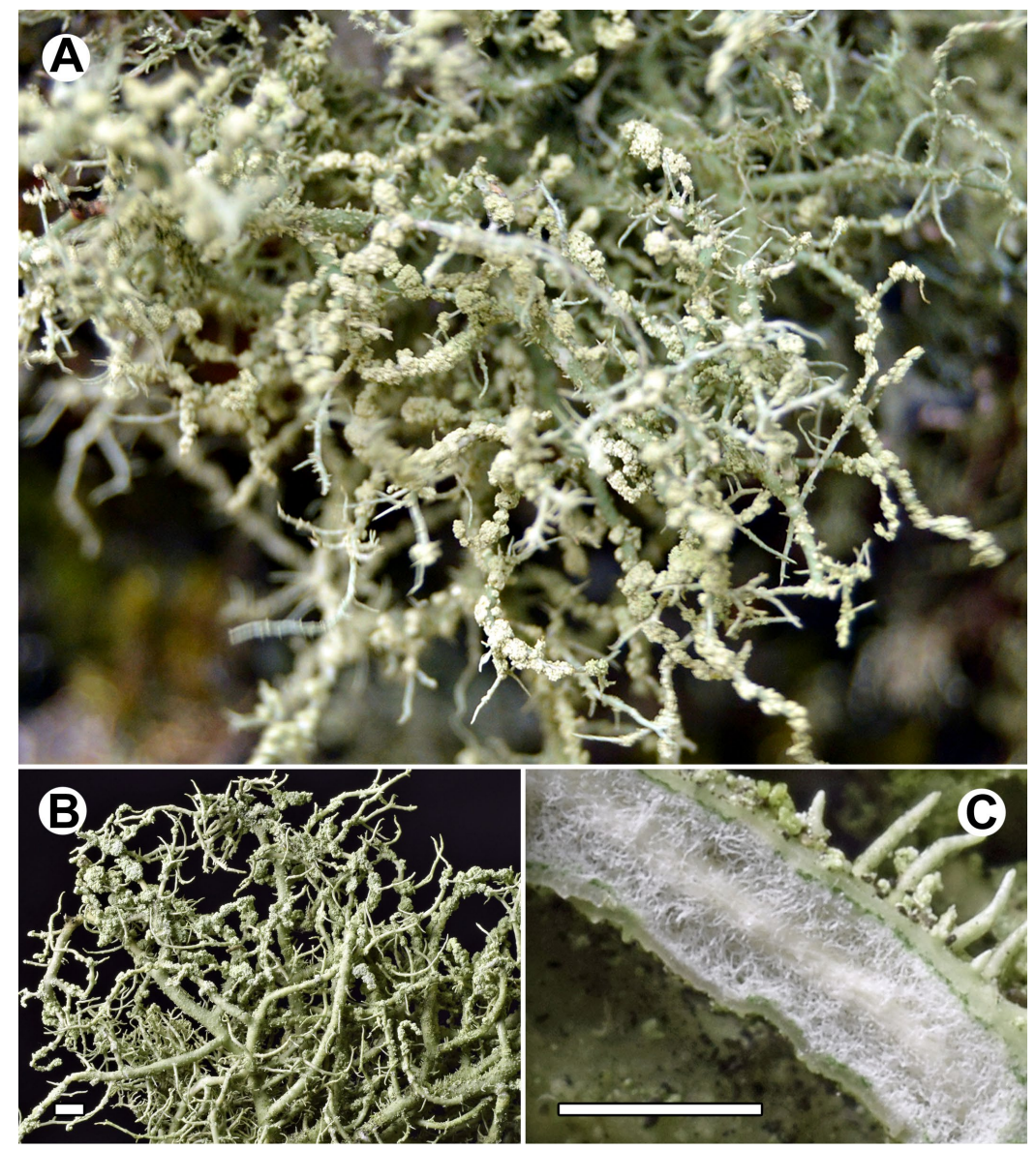

Figure 17. Usnea aff. subpectinata 1 (DB22672; Moncada \& Lücking 41100). A - general habit; B - detail; C - section showing CMA. Scale = 1 mm.

sorediate Colombian sample (DB22672) from the sorediate Ecuadorian specimen (JQ837295), whereas the latter would appear conspecific with the apotheciate Colombian material (MON5866). Given the morphological and chemical congruence between the two sorediate specimens, one could also consider all three to belong to the same species in a broad sense, likely reflecting a complex situation as found in some other so-called species pairs, such as Usnea florida (L.) F.H. Wigg. versus U. subfloridana Stirt. (Mark et al. 2016; Lücking et al. 2020c).

The apotheciate specimen from Colombia (MON5866) corresponds morphologically, anatomically and chemically to Usnea concinna Stirt., described from Brazil (Stirton 1881; Gerlach et al. 2017). Currently, there are no sequence data for the latter, so this hypothesis cannot be tested, but the species has been reported from Colombia under the name $U$. radiata Stirt. (Sipman \& Aguirre-C. 2016), a synonym of $U$. concinna (Gerlach et al. 2017; Lücking et al. 2020d).
Specimens examined. Usnea aff. subpectinata 1 (DB22672): COLOMBIA. Bogotá, D.C. Vereda Pasquilla, 2 km SW of Pasqui1la, along rural access road; $04^{\circ} 25^{\prime} 52^{\prime \prime} \mathrm{N}, 74^{\circ} 10^{\prime} 19^{\prime \prime} \mathrm{W}, 3365 \mathrm{~m}$; disturbed shrubby subparamo remnants bordering pasture; 3 December 2015; B. Moncada \& R. Lücking (with D. Cabrera \& J. Muñoz) 41100 [B (B 60 0200045), JBB]. Usnea aff. subpectinata 2 (MON5866): Cundinamarca. La Calera, Parque Nacional Natural Chingaza, $2 \mathrm{~km}$ before Valle de los Frailejones; 04³6'38. $8^{\prime \prime} \mathrm{N}$, $73^{\circ} 42^{\prime} 54.4^{\prime \prime} \mathrm{W}, 3035 \mathrm{~m}$; paramo, on twig of shrub; 27 February 2017, B. Moncada, R. Lücking, M. Gutiérrez, J. González \& R. Galindo 10870 [B (B 60 0200049), UDBC (C-0022116)].

\section{Usnea tenuicorticata P. Clerc \& A. Gerlach}

Usnea tenuicorticata Gerlach et al., Pl. Fung. Syst. 65(2): 288. 2020.

Type: PORTUGAL: Madeira. Ribeiro Frio, P. Clerc s.n. [G - holotype (G00285250); photograph seen: Gerlach et al. 2020: 289].

Notes. This sample (DB22638; Moncada \& Lücking 41067) clustered with strong support with a specimen

Table 5. ITS-based similarities between the four sequenced samples in the northern Andean Usnea aff. subpectinata clade.

\begin{tabular}{l|l|l|l|c|c|c|c}
\hline Specimen & Country & Morphology & \multicolumn{1}{|c|}{ Chemistry } & JQ837298 & DB22672 & MON5866 & JQ837295 \\
\hline JQ837298 & Peru & sorediate & galbinic & - & $97.3 \%$ & $98.3 \%$ & $97.9 \%$ \\
DB22672 & Colombia & sorediate & stictic & $97.3 \%$ & - & $98.1 \%$ & $97.7 \%$ \\
MON5866 & Colombia & apotheciate & norstictic, stictic & $98.3 \%$ & $98.1 \%$ & - & $99.5 \%$ \\
JQ837295 & Ecuador & sorediate & stictic & $97.9 \%$ & $97.7 \%$ & $99.5 \%$ & - \\
\hline
\end{tabular}




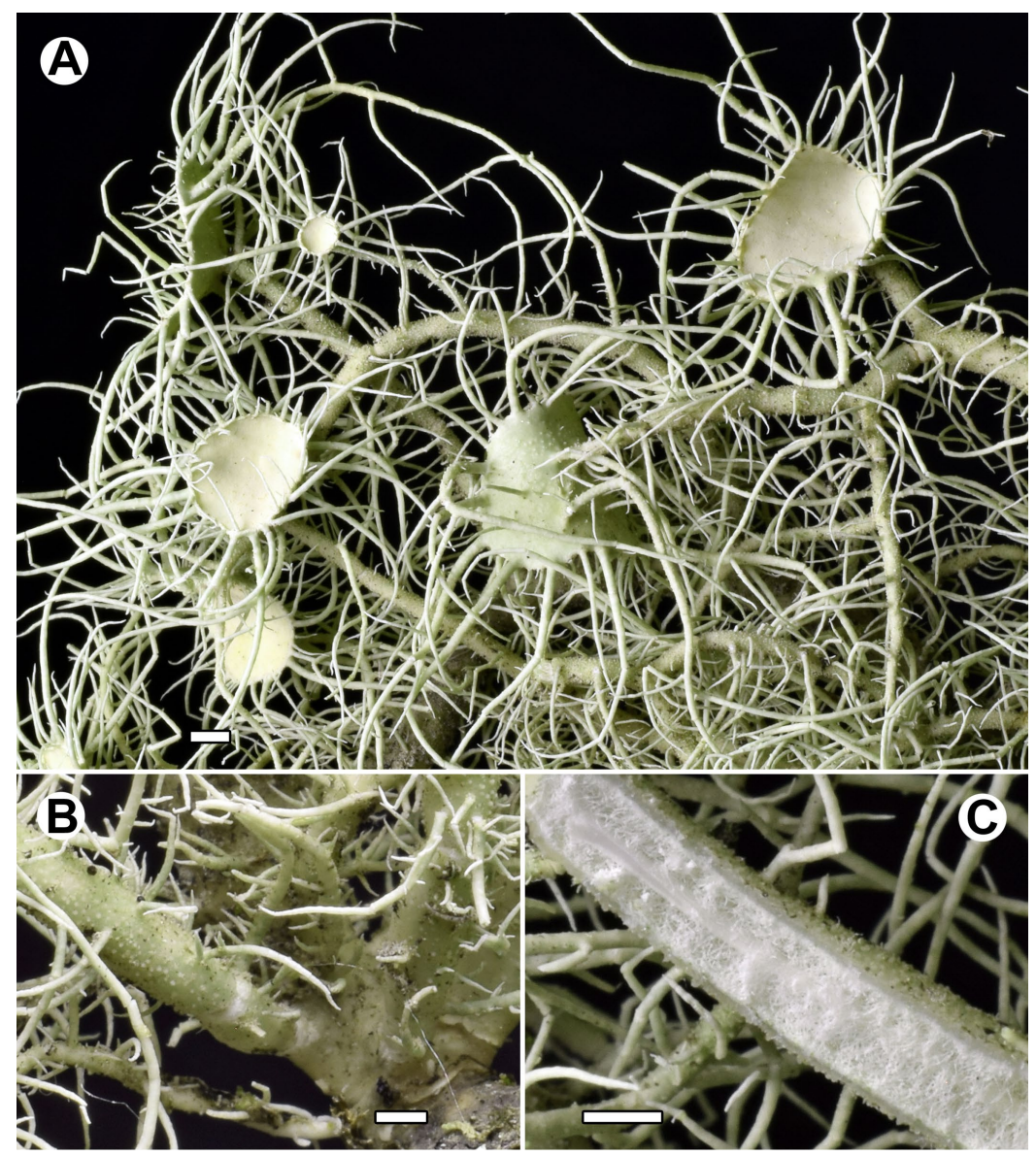

Figure 18. Usnea aff. subpectinata 2 (MON5866; Moncada et al. 10870). A - general habit; B - detail; C - section showing CMA. Scale = 1 mm.

from Madeira representing the type of the recently described Usnea tenuicorticata, a segregate within the U. cornuta complex (Gerlach et al. 2019, 2020). In the study by Gerlach et al. (2019), the sample from Madeira, with protocetraric acid only, formed a separate lineage (lineage 4) compared to the two specimens from Brazil with protocetraric and psoromic acids (lineage 2). In the global ITS tree, the three specimens formed an unsupported clade (Lücking et al. 2020c), whereas the Colombian sample clustered with strong support with the specimen from Madeira (Fig. 4; Fig. S1). It also agreed morphologically and chemically with the latter, forming shrubby thalli with small soralia with isidiomorphs (Fig. 19) and producing protocetraric acid (Fig. 7) as a major compound. A second (minor) spot detected in the Colombian specimen would fit thamnolic acid, but this needs to be confirmed with more material.

Specimen examined. COLOMBIA. Bogotá, D.C. Vereda Pasquilla, $2 \mathrm{~km} \mathrm{SW}$ of Pasquilla, along rural access road; $04^{\circ} 25^{\prime} 52^{\prime \prime} \mathrm{N}, 74^{\circ} 10^{\prime} 19^{\prime \prime} \mathrm{W}, 3365 \mathrm{~m}$; disturbed shrubby subparamo remnants bordering pasture, on rock; 3 December 2015; B. Moncada \& R. Lücking (with D. Cabrera \& J. Muñoz) 41067 [B (B 60 0200043), JBB].

\section{Usnea wasmuthii Räsänen}

Usnea wasmuthii Räsänen, Flecht. Estl. 1: 19. 1931.

Type: Estonia, Harjumaa, Wasmuth s.n. ( $\mathrm{H}$ - holotype; digital image seen: https://plants.jstor.org/stable/viewer/10.5555/ al.ap.specimen.h9500427).
Notes. Usnea wasmuthii is a largely European species, characterized by a mostly shrubby thallus with thick cortex and producing large soralia, with a complex chemistry, but mostly with barbatic acid as main medullary substance (Halonen et al. 1999; Randlane et al. 2009; Saag et al. 2011). It has also been reported from North America including Mexico, northern Africa, and Asia (Halonen 2000; Ohmura 2001, 2012; Clerc 2007; Herrera-Campos 2016; Galinato et al. 2018). ITS data demonstrated at least one Japanese sample to represent this taxon, which could therefore be considered as having a Northern Hemisphere distribution (Lücking et al. 2020c). Recently, Diaz-Escandón et al. (2016) reported the species for the first time from Colombia.

The sequenced specimen (DB22576; Moncada \& Lücking 41018b) confirms this report, as it clustered with the Usnea wasmuthii clade (Fig. 4; Fig. S1). It is also one of the few samples analyzed here that immediately gave the correct identification using ITS barcoding via NCBI BLAST (Table 2). The morphology of the material agreed well with $U$. wasmuthii, in particular the large soralia and the thick cortex (Fig. 20); barbatic acid was identified as (minor) medullary substance (Fig. 7).

Specimen examined. COLOMBIA. Bogotá, D.C. Vereda Pasquilla, $2 \mathrm{~km}$ SW of Pasquilla, along rural access road; $04^{\circ} 25^{\prime} 52^{\prime \prime} \mathrm{N}, 7^{\circ} 10^{\prime} 19^{\prime \prime} \mathrm{W}, 3365 \mathrm{~m}$; disturbed shrubby subparamo remnants bordering pasture, on fence post; 3 December 2015; B. Moncada \& R. Lücking (with D. Cabrera \& J. Muñoz) 41018b [B (B 60 0200038), JBB]. 


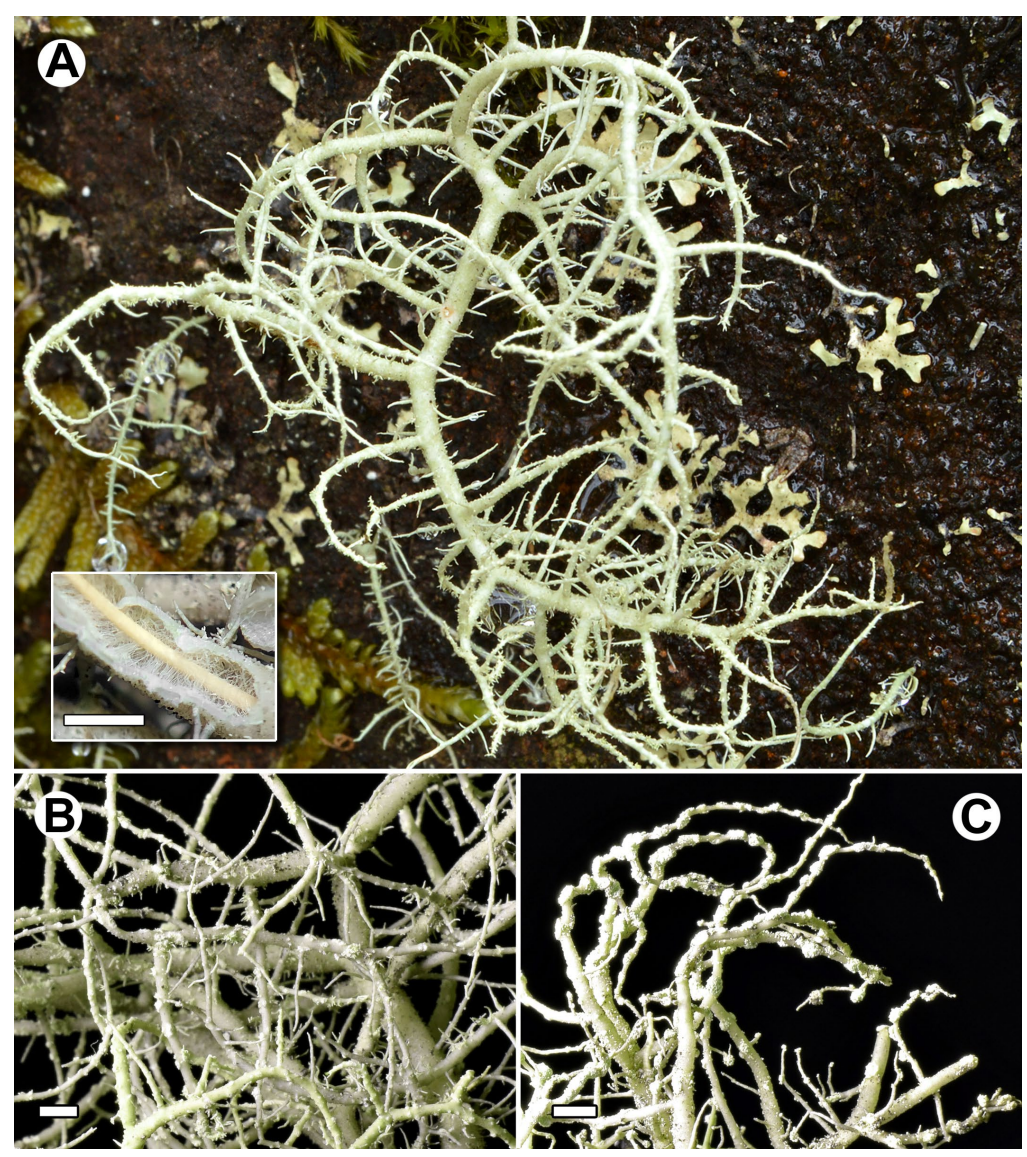

Figure 19. Usnea tenuicorticata (DB22638; Moncada \& Lücking 41067). A - general habit with inset showing CMA; B-C - detail, in C showing soralia along terminal branches. Scale $=1 \mathrm{~mm}$.

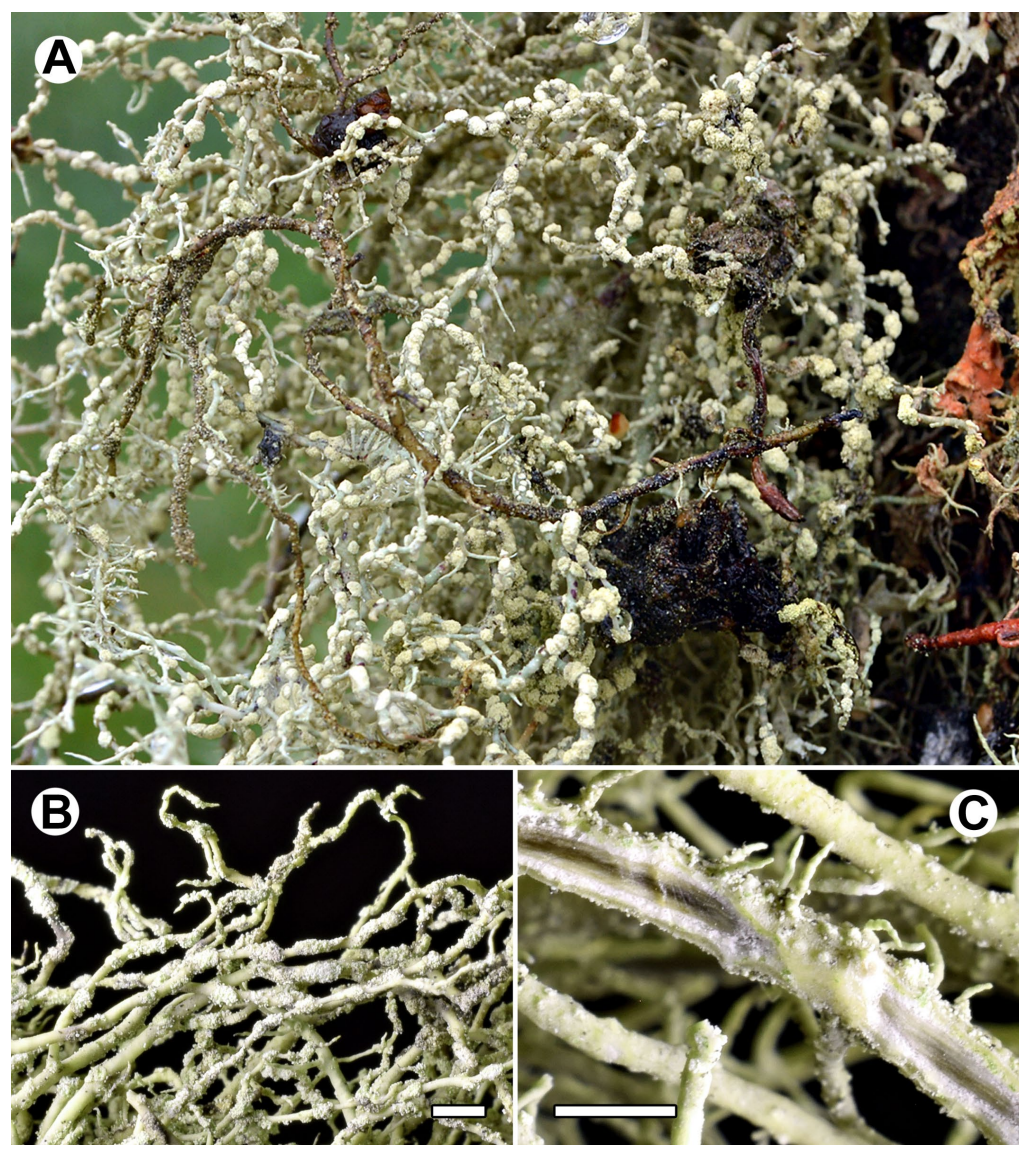

Figure 20. Usnea wasmuthii (DB22576; Moncada \& Lücking 41018b). A - general habit; B - detail; C - section showing CMA. Scale $=1 \mathrm{~mm}$. 


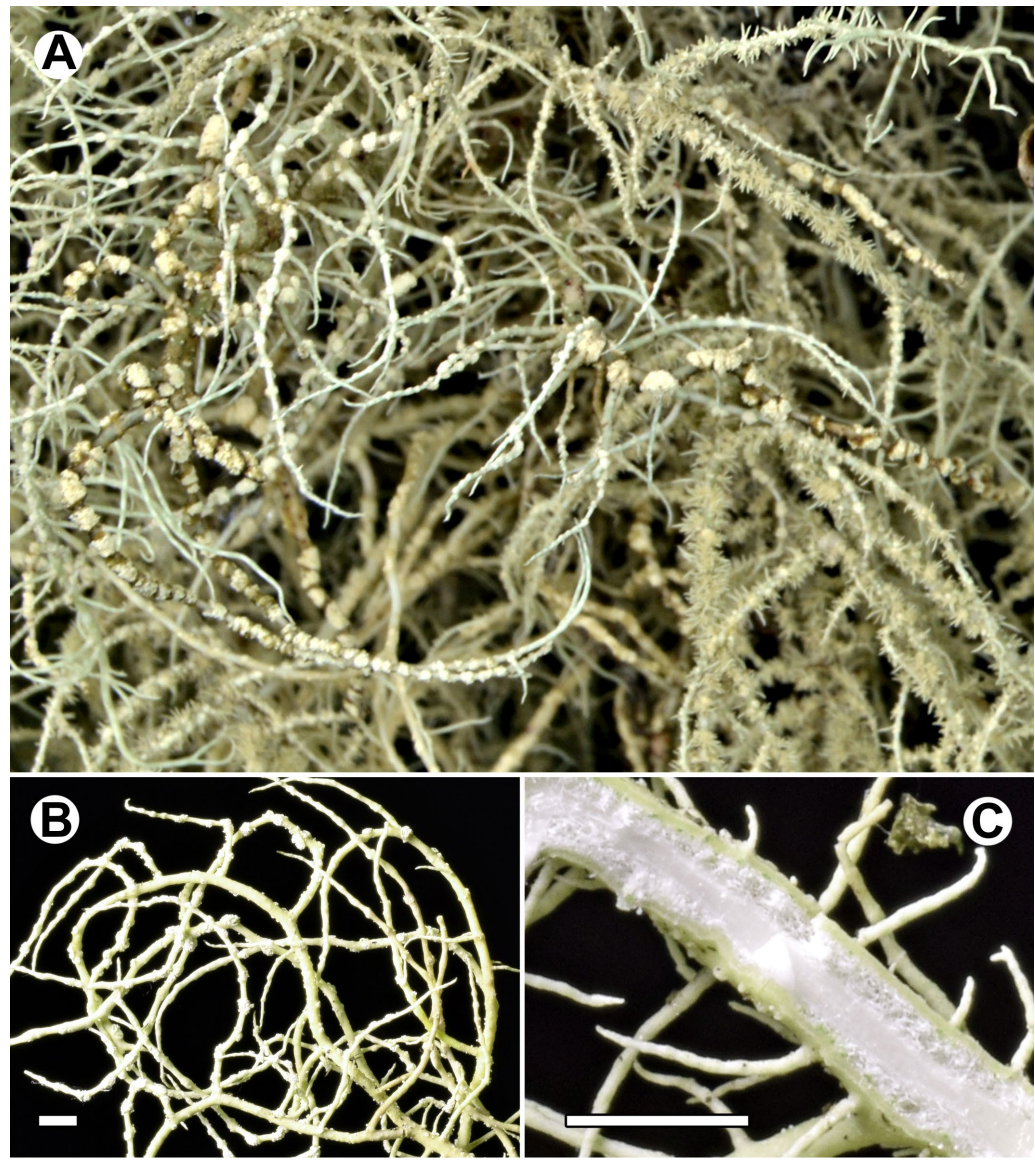

Figure 21. Usnea aff. wasmuthii (DB22609; Moncada \& Lücking 41048a). A - general habit; B - detail; C - section showing CMA. Scale = 1 mm.

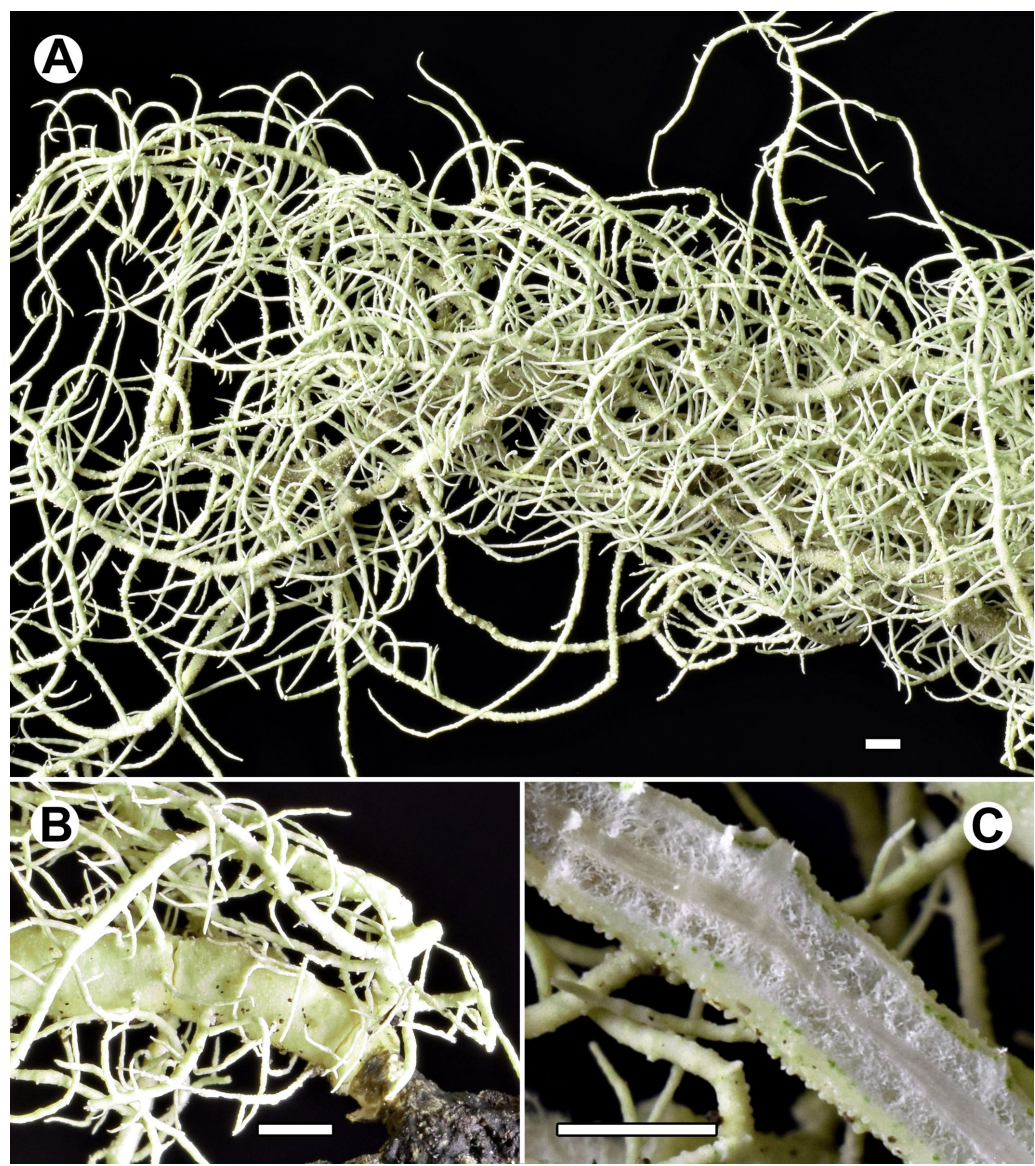

Figure 22. Usnea sp. 1 (MON6230; Moncada \& Patiño 11272b). A - general habit; B - detail (base); C - section showing CMA. Scale = 1 mm. 


\section{Usnea aff. wasmuthii Räsänen}

Usnea wasmuthii Räsänen, Flecht. Estl. 1: 19. 1931.

Type: See previous entry.

Notes. This material (DB22609; Moncada \& Lücking 41048a) formed a fully supported clade with another specimen identified as $U$. aff. glabrata (DB22625; Moncada \& Lücking 41058c; see above). As mentioned above, the two samples had minor differences in the base patterns in two positions (File S1). DB22609 differed from DB22625 in the partly papillose surface, the numerous fibrils, and the soralia becoming large (Fig. 21), as well as the production of barbatic acid (minor; Fig. 7). These characters point to $U$. wasmuthii, but the sample was phylogenetically distinct from the latter, including the Colombian specimen identified as $U$. wasmuthii above.

Specimen examined. COLOMBIA. Bogotá, D.C. Vereda Pasquilla, $2 \mathrm{~km} \mathrm{SW}$ of Pasquilla, along rural access road; $04^{\circ} 25^{\prime} 52^{\prime \prime} \mathrm{N}, 7^{\circ} 10^{\prime} 19^{\prime \prime} \mathrm{W}, 3365 \mathrm{~m}$; disturbed shrubby subparamo remnants bordering pasture, on twig; 3 December 2015; B. Moncada \& R. Lücking (with D. Cabrera \& J. Muñoz) 41048a [B (B 60 0200041), JBB].

Usnea sp. 1

Notes. This material (MON6230; Moncada \& Patiño $11272 b$ ) represents a subpendent species with punctiform soralia mainly developed along the terminal branches, numerous fibrils, and a papillose surface (Fig. 22); succinprotocetraric acid was produced as major secondary compound (Fig. 7). The latter substance is comparatively rare in Usnea, being for instance found in the entirely unrelated $U$. aurantiacoatra in subgen. Neuropogon (Elix et al. 2007). The specimen blasted with $U$. aff. ceratina Ach. and U. halei $\mathrm{P}$. Clerc at around 97\% percentage identity (Table 2, 3), but did not associate with these in the phylogenetic analysis and did not have a close relative (Fig. 4; Fig. S1). Its identity remained unclear.

Specimen examined. COLOMBIA. Putumayo. San Francisco, Vereda Siberia, surroundings of television station; $01^{\circ} 08^{\prime} 44^{\prime \prime} \mathrm{N}$, $76^{\circ} 50^{\prime} 43^{\prime \prime} \mathrm{W}, 2805 \mathrm{~m}$; partially preserved altoandine cloud forest, on bark of Pinus radiata; 24 February 2018, B. Moncada \& A. L. Patiño 11272b [B (B 60 0200053), UDBC (C-0023632)].

\section{Acknowledgements}

The Universidad Distrital Francisco José de Caldas, Bogotá, is thanked for the support to the lichen herbarium and the curatorial work of the UDBC collections. The Jardín Botánico de Bogotá José Celestino Mutis organized field trips to Peña Blanca and Pasquilla (Bogotá), during which some of the specimens were collected, by agreement with the Botanical Garden and Botanical Museum Berlin, partially financed through the German Federal Ministry of Education and Research (BMBF; Pilotprojekt Kooperation mit dem Botanischen Garten Bogotá, Förderkennzeichen 01DN13030; Kooperation mit dem Botanischen Garten Bogotá und der Universidad del Norte Barranquilla, 'ColBioDiv', Förderkennzeichen 01DN17006). The Verein der Freunde des Botanischen Gartens und Botanischen Museums Berlin-Dahlem e.V. [https://www.bgbm.org/de/BGBM/freunde/index.html] supported molecular sequencing work for specimens collected as part of the Pilotprojekt Kooperation mit dem Botanischen Garten
Bogotá. Teuvo Ahti, Alice Gerlach, and María de los Ángeles Herrera-Campos helped in resolving part of the taxonomy of the study samples and the nomenclature of the underlying names, Jack Elix was consulted for the interpretation of some of the TLC spots, and Andreas Beck assisted with a query for type specimens housed at $\mathrm{M}$.

\section{Supplementary electronic material}

Figure S1. Best-scoring, ITS-based maximum likelihood tree of Usnea s.str. (subgenus Usnea) showing the position of the query sequences from Colombia. Download file

File S1. ITS alignment of Usnea s.str. (subgenus Usnea) for the phylogenetic analysis of the query sequences. Download file

\section{References}

Abarenkov, K., Henrik Nilsson, R., Larsson, K. H., Alexander, I. J., Eberhardt, U., Erland, S., Høiland, K., Kjøller, R., Larsson, E., Pennanen, T. \& Sen, R. 2010. The UNITE database for molecular identification of fungi - recent updates and future perspectives. New Phytologist 186: 281-285.

Altschul, S. F., Gish, W., Miller, W., Myers, E. W. \& Lipman, D. J. 1990. Basic local alignment search tool. Journal of Molecular Biology 215: 403-410.

Begerow, D., Nilsson, H., Unterseher, M. \& Maier, W. 2010. Current state and perspectives of fungal DNA barcoding and rapid identification procedures. Applied Microbiology and Biotechnology 87: 99-108.

Bengtsson-Palme, J., Ryberg, M., Hartmann, M., Branco, S., Wang, Z., Godhe, A., De Wit, P., Sánchez-García, M., Ebersberger, I., de Sousa, F. \& Amend, A. 2013. Improved software detection and extraction of ITS1 and ITS 2 from ribosomal ITS sequences of fungi and other eukaryotes for analysis of environmental sequencing data. Methods in Ecology and Evolution 4: 914-919.

Bidartondo, M. 2008 Preserving accuracy in GenBank. Science 319: 1616.

Bungartz, F., Truong, C., Herrera-Campos, M. A. \& Clerc, P. 2018. The genus Usnea (Parmeliaceae, Lecanoromycetes) in the Galapagos Islands. Herzogia 31: 571-629.

Camacho, C., Coulouris, G., Avagyan, V., Ma, N., Papadopoulos, J., Bealer, K. \& Madden, T. L. 2009. BLAST+: architecture and applications. BMC Bioinformatics 10: 421.

Clerc, P. 1987. Systematics of the Usnea fragilescens aggregate and its distribution in Scandinavia. Nordic Journal of Botany 7: 479-495.

Clerc, P. 2004. Notes on the genus Usnea Adanson. II. Bibliotheca Lichenologica 88: 79-90.

Clerc, P. 2006. Synopsis of Usnea (lichenized Ascomycetes) from the Azores with additional information on the species in Macaronesia. The Lichenologist 38: 191-212.

Clerc, P. 2007. Usnea. In: Nash, T. H. III, Gries, C. \& Bungartz, F. (eds), Lichen Flora of the Greater Sonoran Desert Region, Vol. 3, pp. 302-335. Lichens Unlimited, Arizona State University, Tempe.

Clerc, P. 2016. Notes on the genus Usnea (lichenized Ascomycota, Parmeliaceae) IV. Herzogia 29: 403-411.

Clerc, P. \& Otte, V. 2018. Usnea viktoriana (Ascomycota, Parmeliaceae), a new European taxon of the Usnea barbata-dasopoga group, with a key to the shrubby-subpendulous sorediate Usnea species in Europe. The Lichenologist 50: 513-527.

Díaz-Escandón, D., Soto- Medina, E., Lücking, R. \& Silverstone-Sopkin, P. A. 2016: Corticolous lichens as environmental indicators of natural sulphur emissions near the sulphur mine El Vinagre (Cauca, Colombia). The Lichenologist 48: 147-159.

Dorey, J. E., Hoffman, J. R., Martino, J. L., Lendemer, J. C. \& Allen, J. L. 2019. First record of Usnea (Parmeliaceae) growing in New 
York City in nearly 200 years. The Journal of the Torrey Botanical Society 146: 69-77.

Elix, J. A., Wirtz, N. \& Lumbsch, H. T. 2007. Studies on the chemistry of some Usnea species of the Neuropogon group (Lecanorales, Ascomycota). Nova Hedwigia 85: 491-501.

Edgar, R. C. 2018. Accuracy of taxonomy prediction for 16S rRNA and fungal ITS sequences. PeerJ 6: e4652.

Esslinger, T. L. 2019. A cumulative checklist for the lichen-forming, lichenicolous and allied fungi of the continental United States and Canada, version 23. Opuscula Philolichenum 18: 102-378.

Galinato, M. G. M., Baguinon, J. R. C. \& Santiago, K. A. A. 2018. Review of the lichen genus Usnea in the Philippines. Studies in Fungi 3: 39-48.

Gams, W. 2004. Report of the Committee for Fungi: 11. Taxon 53: 1067-1069.

Gardes, M. \& Bruns, T. D. 1993. ITS primers with enhanced specificity for basidiomycetes - application to the identification of mycorrhizae and rusts. Molecular Ecology 2: 113-118.

Gerlach, A. C. L., Clerc, P. \& Silveira, R. M. B. 2017. Taxonomy of the corticolous, shrubby, esorediate, neotropical species of Usnea Adans. (Parmeliaceae) with an emphasis on southern Brazil. The Lichenologist 49: 199-238.

Gerlach, A. C. L., Toprak, Z., Naciri, Y., Caviró, E. A., Silveira, R. M. B. \& Clerc, P. 2019. New insights into the Usnea cornuta aggregate (Parmeliaceae, lichenized Ascomycota): Molecular analysis reveals high genetic diversity correlated with chemistry. Molecular Phylogenetics and Evolution 131: 125-137. [First published online 30 October 2018]

Gerlach, A, Silveira, R. M. B., Rojas, C. \& Clerc, P. 2020. Naming and describing the diversity in the Usnea cornuta aggregate (lichenized Ascomycota, Parmeliaceae) occurring in Brazil. Plant and Fungal Systematics 65: 272-302.

Grewe, F., Lagostina, E., Wu, H., Printzen, C. \& Lumbsch, H. T. 2018. Population genomic analyses of RAD sequences resolves the phylogenetic relationship of the lichen-forming fungal species Usnea antarctica and Usnea aurantiacoatra. MycoKeys 43: 91-113.

Hall, T. A. 1999. BioEdit: a user-friendly biological sequence alignment editor and analysis program for Windows 95/98/NT. Nucleic Acids Symposium Series 41: 95-98.

Hall, T. 2011. BioEdit: an important software for molecular biology. GERF Bulletin Biosci 2: 60-61.

Halonen, P. 2000. Usnea pacificana, sp. nov. and U. wasmuthii (lichenized Ascomycetes) in Pacific North America. The Bryologist 103: $38-43$.

Halonen, P. \& Ahti, T. 2002. (1516) Proposal to conserve the name Usnea fulvoreagens (lichenized Ascomycota, Parmeliaceae) with a conserved type. Taxon 51: 183-183.

Halonen, P., Clerc, P., Goward, T., Brodo, I. M. \& Wulff, K. 1998. Synopsis of the genus Usnea (lichenized Ascomycetes) in British Columbia, Canada. The Bryologist 101: 36-60.

Halonen, P., Myllys, L., Ahti, T. \& Petrova, O. V. 1999. The lichen genus Usnea in East Fennoscandia. III. The shrubby species. Annales Botanici Fennici 36: 235-256.

Herrera-Campos, M. A. 2016. Usnea in Mexico. Bibliotheca Lichenologica 110: 505-620.

Herrera-Campos, M. A., Nash III, T. H. \& Garcia, A. Z. 2001. Preliminary study of the Usnea fragilescens aggregate in Mexico. The Bryologist 104: 235-259.

Hofstetter, V., Buyck, B., Eyssartier, G., Schnee, S. \& Gindro, K. 2019. The unbearable lightness of sequenced-based identification. Fungal Diversity 96: 243-284.

Huneck, S. \& Yoshimura, I. 1996. Identification of Lichen Substances. Springer, Berlin, Heidelberg.

Irinyi, L., Serena, C., Garcia-Hermoso, D., Arabatzis, M., Desnos-Ollivier, M., Vu, D., Cardinali, G., Arthur, I., Normand, A. C., Giraldo, A., da Cunha, K. C., Sandoval-Denis, M., Hendrickx, M., Nishikaku, A. S., de Azevedo Melo, A. S., Merseguel, K. B., Khan, A., Parente Rocha, J. A., Sampaio, P., da Silva Briones, M. R., Ferreira, R. C., de Medeiros Muniz, M., Castañón-Olivares, L. R., Estrada-Barcenas, D., Cassagne, C., Mary. C., Duan, S. Y., Kong, F., Sun, A. Y., Zeng, X., Zhao, Z., Gantois, N., Botterel, F., Robbertse, B., Schoch. C. L., Gams, W., Ellis, D., Halliday, C., Chen, S., Sorrell, T. C., Piarroux, R., Colombo, A. L., Pais, C., de Hoog, S., Zancopé-Oliveira, R. M., Taylor, M. L., Toriello, C., de Almeida Soares, C. M., Delhaes, L., Stubbe, D., Dromer, F., Ranque, S., Guarro, J., Cano-Lira, J. F., Robert, V., Velegraki, A. \& Meyer W. 2015. International Society of Human and Animal Mycology (ISHAM) - ITS reference DNA barcoding database - The quality controlled standard tool for routine identification of human and animal pathogenic fungi. Medical Mycology 53: 313-337.

Jeewon, R. \& Hyde, K. D. 2016. Establishing species boundaries and new taxa among fungi: recommendations to resolve taxonomic ambiguities. Mycosphere 7: 1669-1677.

Jørgensen, P. M., James, P. W. \& Jarvis, C. E. 1994. Linnaean lichen names and their typification. Botanical Journal of the Linnean Society 115: 261-405.

Kelly, L. J., Hollingsworth, P. M., Coppins, B. J., Ellis, C. J., Harrold, P., Tosh, J. \& Yahr, R. 2011. DNA barcoding of lichenized fungi demonstrates high identification success in a floristic context. New Phytologist 191: 288-300.

Kõljalg, U., Nilsson, R. H., Abarenkov, K., Tedersoo, L., Taylor, A. F. S., Bahram, M., Bates, S. T., Bruns, T. D., Bengtsson-Palme, J., Callaghan, T. M., Douglas, B., Drenkhan, T., Eberhardt, U., Dueñas, M., Grebenc, T., Griffith, G. W., Hartmann, M., Kirk, P. M., Kohout, P., Larsson, E., Lindahl, B. D., Lücking, R., Martín, M. P., Matheny, B., Nguyen, N. H., Niskanen, T., Oja, J., Peay, K. G., Peintner, U., Peterson, M., Oldmaa, K. P., Saag, L., Saar, R., Schüssler, A., Scott, J. A., Senés, C., Smith, M. E., Suija, A., Taylor, D. L., Telleria, M. T., Weiss, M. \& Larsson, K. H. 2013. Towards a unified paradigm for sequence-based identification of Fungi. Molecular Ecology 22: 5271-5277.

Kõljalg, U., Abarenkov, K., Nilsson, R. H., Larsson, K. H. \& Taylor, A. F. 2019. The UNITE Database for Molecular Identification and for Communicating Fungal Species. Biodiversity Information Science and Standards 3: e37402.

Lagostina, E., Dal Grande, F., Andreev, M. \& Printzen, C. 2018. The use of microsatellite markers for species delimitation in Antarctic Usnea subgenus Neuropogon. Mycologia 110: 1047-1057.

Lücking, R., Hodkinson, B. P. \& Leavitt, S. D. 2017a. The 2016 classification of lichenized fungi in the Ascomycota and Basidiomycota - Approaching one thousand genera. The Bryologist 119: 361-416.

Lücking, R., Dal Forno, M., Moncada, B., Coca, L. F., Vargas-Mendoza, 1. Y., Aptroot, A., Arias, L. J., Besal, B., Bungartz, F., CabreraAmaya, D. M., Cáceres, M. E. S., Chaves, J. L., Eliasaro, S., Gutiérrez, M. C., Hernández-M., J. E., Herrera-Campos, M. A., Holgado-Rojas, M. E., Jonitz, H., Kukwa, M., Lucheta, F., Madriñán, S., Marcelli, M. P., Martins, S. M. A., Mercado-Díaz, J. A., Molina, J. A., Morales, E. A., Nelson, P. R., Nugra, F., Ortega, F., Paredes, T., Patiño, A. L., Peláez-Pulido, R. N., Pérez-Pérez, R. E., Perlmutter, G. B., Rivas-Plata, M. E., Robayo, J., Rodríguez, C., Simijaca, D. F., Soto-Medina, E., Spielmann, A. A., Suárez-Corredor, A., Torres, J. M., Vargas, C. A., Yánez-Ayabaca, A., Weerakoon, G., Wilk. K., Celis-Pacheco, M., Diazgranados, M., Brokamp, G., Borsch, T., Gillevet, P. M., Sikaroodi, M. \& Lawrey, J. D. 2017 b. Turbo-taxonomy to assemble a megadiverse lichen genus: seventy new species of Cora (Basidiomycota: Agaricales: Hygrophoraceae), honouring David Leslie Hawksworth's seventieth birthday. Fungal Diversity 84: 139-207.

Lücking, R., Aime, M. C., Robberts, B., Miller, A. N., Ariyawansa, H. A., Aoki, T., Cardinali, G., Crous, P. W., Druzhinina, I. S., Geiser, D. M., Hawksworth, D. L., Hyde, K. D., Irinyi, L., Jeewon, R., Johnston, P. R., Kirk, P. M., Malosso, E., May, T. W., Meyer, W., Öpik, M., Robert, V., Stadler, M., Thines, M., Vu, D., Yurkov, A. M., Zhang, N., Schoch, C. L. 2020a. Unambiguous identification of 
fungi: where do we stand and how accurate and precise is fungal barcoding? IMA Fungus 11: 14.

Lücking, R., Truong, B. V., Huong, D. T. T., Le, N. H., Nguyen, Q. D., Nguyen, V. D., Von Raab-Straube, E., Bollendorff, S., Govers. K. \& Di Vincenzo, V. 2020b. Caveats of fungal barcoding: a case study in Trametes s.lat. (Basidiomycota: Polyporales) in Vietnam reveals multiple issues with mislabelled reference sequences and calls for third-party annotations. Willdenowia 50: 383-403.

Lücking, R., Nadel, M. R. A., Araujo-Caviró, E. \& Gerlach, A. C. L. 2020c. Two decades of DNA barcoding in the genus Usnea (Parmeliaceae): how useful and reliable is the ITS? Plant and Fungal Systematics 65: 303-357.

Lücking, R., Moncada, B., Soto-Medina, E., Simijaca, D. \& Sipman, H. J. M. 2020d. Actualización nomenclatural y taxonómica al Catálogo de Líquenes de Colombia. Revista de la Academia Colombiana de Ciencias Exactas, Físicas y Naturales (in press).

Lumbsch, H. T. \& Wirtz, N. 2011. Phylogenetic relationships of the neuropogonoid core group in the genus Usnea (Ascomycota: Parmeliaceae). The Lichenologist 43: 553-559.

Mark, K., Saag, L., Leavitt, S. D., Will-Wolf, S., Nelsen, M. P., Tõrra, T., Saag, A., Randlane, T. \& Lumbsch, H. T. 2016. Evaluation of traditionally circumscribed species in the lichen-forming genus Usnea, section Usnea (Parmeliaceae, Ascomycota) using a six-locus dataset. Organisms Diversity \& Evolution 16: 497-524.

Menlove, K. J., Clement, M. \& Crandall, K. A. 2009. Similarity searching using BLAST. In: Posada, D. (ed.), Bioinformatics for DNA Sequence Analysis, pp. 1-22. Humana Press, New York.

Miller, M. A., Pfeiffer, W. \& Schwartz, T. 2010. Creating the CIPRES Science Gateway for inference of large phylogenetic trees. In: Proceedings of the Gateway Computing Environments Workshop (GCE), pp. 1-8. New Orleans.

Moncada, B., Lücking, R. \& Suárez, A. 2014. Molecular phylogeny of the genus Sticta (lichenized Ascomycota: Lobariaceae) in Colombia. Fungal Diversity 64: 205-231.

Motyka, J. 1938. Lichenum Generis Usnea Studium Monographicum. Pars Systematica, Volumen Secundum. Leopoli, Lublin.

Nilsson, R. H., Ryberg, M., Kristiansson, E., Abarenkov, K., Larsson, K. H. \& Kõljalg, U. 2006. Taxonomic reliability of DNA sequences in public sequence databases: a fungal perspective. PloS One 1(1): e59.

Nilsson, R. H., Tedersoo, L., Abarenkov, K., Ryberg, M., Kristiansson, E., Hartmann, M., Schoch, C. L., Nylander, J. A., Bergsten, J., Porter, T. M., Jumpponen, A., Vaishampayan, P., Ovaskainen, O., Hallenberg, N., Bengtsson-Palme, J., Eriksson, K. M., Larsson, K.-H., Larsson, E. \& Kõljalg, U. 2012. Five simple guidelines for establishing basic authenticity and reliability of newly generated fungal ITS sequences. MycoKeys 4: 37-63.

Nilsson, R. H, Larsson, K.-H., Taylor, A. F. S., Bengtsson-Palme, J., Jeppesen, T. S., Schigel, D., Kennedy, P., Picard, K., Glöckner, F. O., Tedersoo, L., Saar, I., Kõljalg, U. \& Abarenkov, K. 2019. The UNITE database for molecular identification of fungi: handling dark taxa and parallel taxonomic classifications. Nucleic Acids Research 47(D1): D259-D264.

Ohmura, Y. 2001. Taxonomic study of the genus Usnea (lichenized Ascomycetes) in Japan and Taiwan. Journal of the Hattori Botanical Laboratory 90: 1-96.

Ohmura, Y. 2012. A synopsis of the lichen genus Usnea (Parmeliaceae, Ascomycota) in Taiwan. Memories of the National Science Museum Tokyo 48: 91-137.

Orange, A., James, P. W. \& White, F. J. 2001. Microchemical Methods for the Identification of Lichens. 2nd Edition. British Lichen Society, London.

Pearson, W. R. 2013. An introduction to sequence similarity ('homology') searching. Current Protocols in Bioinformatics 42: 3.1.1-3.18.

Pulido-Herrera, K. \& Ramos-Montaño, C. 2016. Efecto de borde en la distribución de líquenes y el contenido de clorofilas en fragmentos de Polylepis quadrijuga (Rosaceae) en el páramo de La Rusia (Boyacá-Colombia). Revista de Biología Tropical 64: 1683-1697.
Ramírez-Morán, N. A., León-Gómez, M. \& Lücking, R. 2015. Uso de biotipos de líquenes como indicadores de perturbación en dos fragmentos de bosque andino, Reserva Biológica 'Encenillo', Colombia. Caldasia 38: 31-52.

Randlane, T., Tõrra, T., Saag, A. \& Saag, L. 2009. Key to European Usnea species. Bibliotheca Lichenologica 100: 419-462.

Räsänen, V. 1931. Die Flechten Estlands. 1. Annales Academiae Scientiarum Fennicae, Ser. A, 34: 1-163.

Räsänen, V. 1935. Lichenes Fenniae Exsiccati, a Museo Botanico Universitatis Helsinkiensis Edita. Fasc. I (nos. 1-50), curavit V. Räsänen: no. 13 .

Räsänen, V. 1936. Collationes ad lichenologiam Chilensem pertinentes. Revista Universitaria Santiago 21: 137-148.

Räsänen, V. 1939. Die Flechtenflora der Nordlichen Kustengegend am Laatokka-See. Annales Botanici Societatis Zoologicae-Botanicae Fennicae Vanamo 12: 1-240.

Ryan, D. 2018. Global Plants: A model of international collaboration. Biodiversity Information Science and Standards 2: e28233.

Saag, L., Tõrra, T., Saag, A., Del-Prado, R. \& Randlane, T. 2011. Phylogenetic relations of European shrubby taxa of the genus Usnea. The Lichenologist 43: 427-444.

Schoch, C. L., Seifert, K. A., Huhndorf, S., Robert, V., Spouge, J. L., Levesque, C. A., Chen, W. \& Fungal Barcoding Consortium. 2012. Nuclear ribosomal internal transcribed spacer (ITS) region as a universal DNA barcode marker for Fungi. Proceedings of the National Academy of Sciences of the United States of America 109: 6241-6246.

Seymour, F. A., Crittenden, P. D., Wirtz, N., Øvstedal, D. O., Dyer, P. S. \& Lumbsch, H. T. 2007. Phylogenetic and morphological analysis of Antarctic lichen-forming Usnea species in the group Neuropogon. Antarctic Science 19: 71-82.

Shen, Y. M., Hsieh, H. J., Yeh, R. Y. \& Hung, T. H. 2012. Five apothecium-producing lichenized fungi of the genus Usnea in Taiwan. Fungal Science 27: 31-44.

Simijaca, D., Moncada, B. \& Lücking, R. 2018. Bosque de roble o plantación de coníferas, ¿qué prefieren los líquenes epífitos? Colombia Forestal 21: 123-141.

Sipman, H. J. M. \& Aguirre-C., J. 2016. Líquenes. In: Bernal, R., Gradstein, S. R. \& Celis, M. (eds), Catálogo de Plantas y Liquenes de Colombia. Volumen 1, pp. 159-281. Universidad Nacional de Colombia, Facultad de Ciencias, Instituto de Ciencias Naturales, Bogotá.

Stirton, J. 1881. On the genus Usnea and a new genus allied to it. Scottish Naturalist 6: 100-107.

Tavares, I. I. 2002. Notes on lectotypification of Usnea fulvoreagens, $U$. gigantea, U. sulcata, and U. cavernosa. Constancea 83: 1-5.

Tedersoo, L., Abarenkov, K., Nilsson, R. H., Schüssler, A., Grelet, G. A., Kohout, P., Oja, J., Bonito, G. M., Veldre, V., Jairus, T., Ryberg, M., Larsson, K.-H. \& Kõljalg, U. 2011. Tidying up international nucleotide sequence databases: ecological, geographical and sequence quality annotation of ITS sequences of mycorrhizal fungi. PLoS One 6(9): e24940.

Tedersoo, L., Anslan, S., Bahram, M., Põlme, S., Riit, T., Liiv, I., Kõljalg, U., Kisand, V., Nilsson, H., Hildebrand, F., Bork, P. \& Abarenkov, K. 2015. Shotgun metagenomes and multiple primer pair-barcode combinations of amplicons reveal biases in metabarcoding analyses of fungi. MycoKeys 10: 1-43.

Temu, S. G., Clerc, P., Tibell, L., Tibuhwa, D. D., Tibell, S. 2019. Phylogeny of the subgenus Eumitria in Tanzania. Mycology 10: 250-260.

Truong, C. \& Clerc, P. 2012. The lichen genus Usnea (Parmeliaceae) in tropical South America: species with a pigmented medulla, reacting C+ yellow. The Lichenologist 44: 625-637.

Truong, C. \& Clerc, P. 2016. New species and new records in the genus Usnea (Parmeliaceae, lichenized Ascomycota) from tropical South America. The Lichenologist 48: 71-93. 
Truong, C., Bungartz, F. \& Clerc, P. 2011. The lichen genus Usnea (Parmeliaceae) in the tropical Andes and the Galapagos: species with a red-orange cortical or subcortical pigmentation. The Bryologist 114: 477-503.

Truong, C., Divakar, P. K., Yahr, R., Crespo, A. \& Clerc, P. 2013a. Testing the use of ITS rDNA and protein-coding genes in the generic and species delimitation of the lichen genus Usnea (Parmeliaceae, Ascomycota). Molecular Phylogenetics and Evolution 68: 357-372.

Truong, C., Rodridguez, J. M. \& Clerc, P. 2013b. Pendulous Usnea species (Parmeliaceae, lichenized Ascomycota) in tropical South America and the Galapagos. The Lichenologist 45: 505-542.

Truong, C., Mujic, A. B., Healy, R., Kuhar, F., Furci, G., Torres, D., Niskanen, T., Sandoval-Leiva, P. A., Fernández, N., Escobar, J. M. \& Moretto, A. 2017. How to know the fungi: combining field inventories and DNA-barcoding to document fungal diversity. New Phytologist 214: 913-919.

Vareschi, V. 2001. El genero Usnea en Venezuela. Boletín de la Academia de Ciencias Físicas, Matemáticas y Naturales 61: 9-63.
Vilgalys, R. 2003. Taxonomic misidentification in public DNA databases. New Phytologist 160: 4-5.

White, T. J., Bruns, T., Lee, S. \& Taylor, J. 1990. Amplification and direct sequencing of ribosomal RNA genes and the internal transcribed spacer in fungi. In: Innis, M. A., Gelfand, D. H., Sninsky, J. J. \& White, T. H. (eds), PCR-Protocols and Applications - A Laboratory Manual, pp. 315-322. Academic Press, New York.

Wirtz, N., Printzen, C. \& Lumbsch, H. T. 2008. The delimitation of Antarctic and bipolar species of neuropogonoid Usnea (Ascomycota, Lecanorales): a cohesion approach of species recognition for the Usnea perpusilla complex. Mycological Research 112: $472-484$.

Wirtz, N., Printzen, C. \& Lumbsch, H. T. 2012. Using haplotype networks, estimation of gene flow and phenotypic characters to understand species delimitation in fungi of a predominantly Antarctic Usnea group (Ascomycota, Parmeliaceae). Organisms Diversity \& Evolution 12: 17-37.

Xu, J. 2016. Fungal DNA barcoding. Genome 59: 913-932. 